\title{
Alternative Policies for the Control of Air Pollution in Poland
}

Robin Bates, Janusz Cofala, and Michael Toman

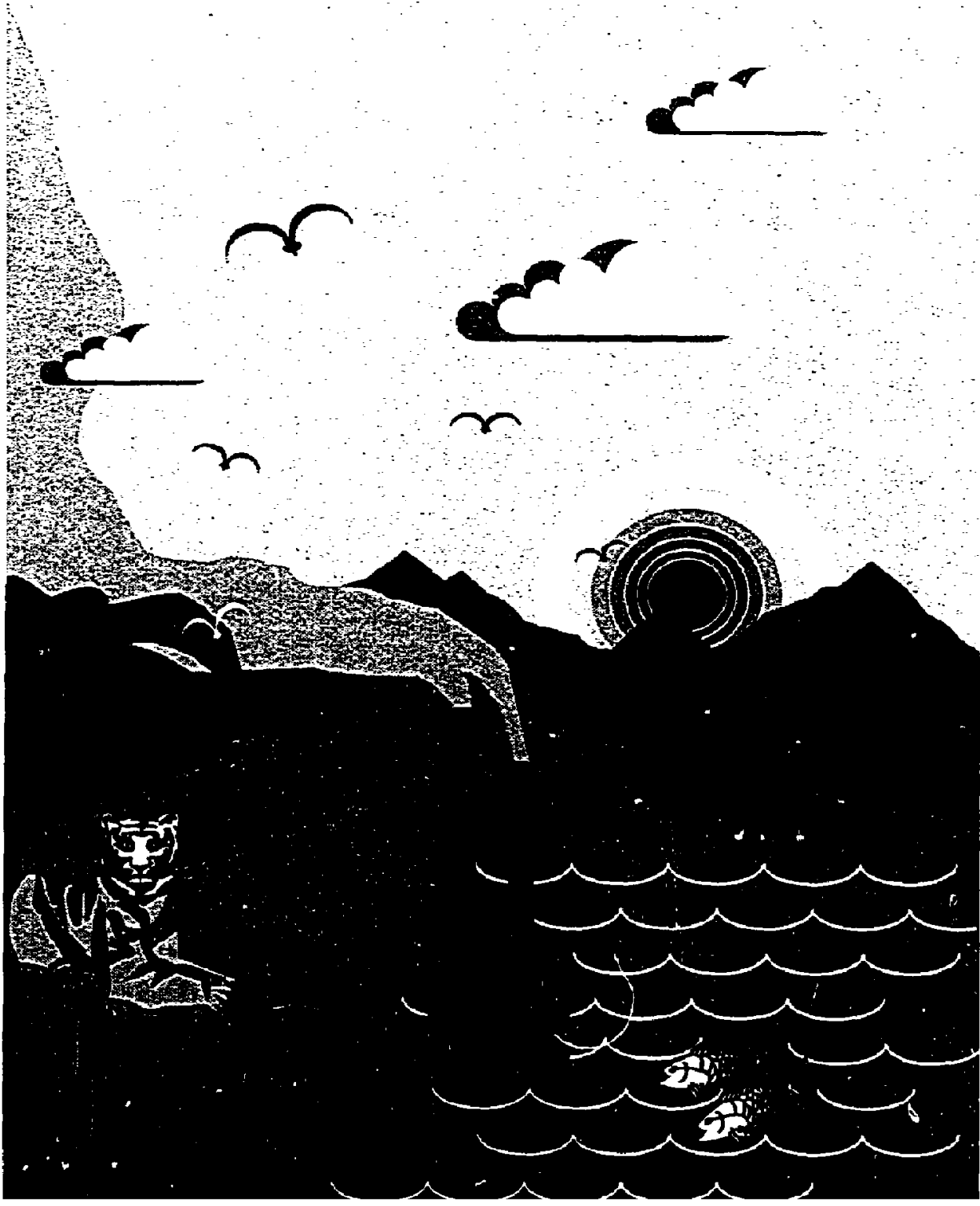




\section{RECENT IVORLD BANK ENVIRONMENT PAIERS}

No. I Cleaver, Munasinghe, Dyson, Egli, Peuker, and IVencejlius, editors, Comsirintivll of lVest and Cint ral

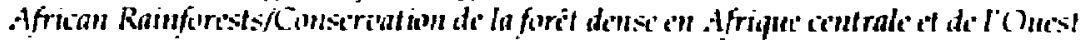

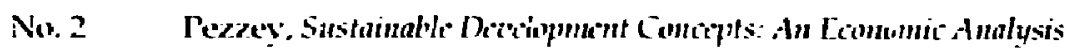

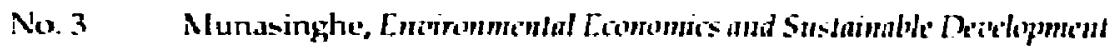

Niv. 4 Deweres, Trees. Land. and Labor

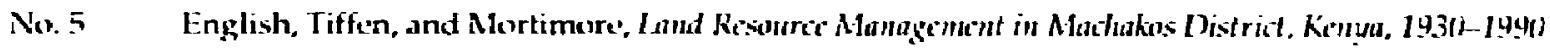

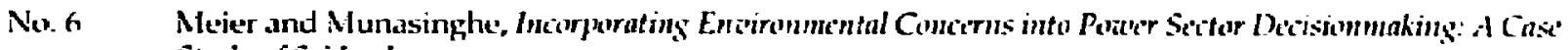
Study of Sri lamka 
WORLD BANK ENVIRONMENT PAPER NUMBER 7

\section{Alternative Policies for the Control of Air Pollution in Poland}

Robin Bates, Janusz Cofala, and Michael Toman

The World Bank

Washington, D.C. 
Copyright 01994

The International Bank for Reconstruction

and Development/THE WORLD BANK

1818 H Street, N.W.

Washington, D.C. 20433, U.S.A.

All rights reserved

Manufactured in the United States of America

First printing March 1994

Environment Papers are published to communicate the latest results of the Bank's environmental work to the development community with the least possible delay. The typescript of this paper therefore has nol been prepared in accordance with the procedures appropriate to formal printed texts, and the World Bank accepts no responsibility for errors. Some sources cited in this paper may be informal documents that are not readily available.

The findings, interpretations, and conclusions expressed in this paper are entirely those of the author(s) and should not be attributed in any manner to the World Bank, to its affiliated organizations, or to members of its Board of Executive Directors or the countries they represent. The World Bank does not guarantee the accuracy of the data included in this publication and accepts no responsibility whatsoever for any consequence of their use. The boundaries, colors, denominations, and other information shown on any map in this volume do not imply on the part of the World Bank Group any judgment on the legal status of any territory or the endorsement or acceptance of such boundar ies.

The material in this publication is copyrighted. Requests for permission to reproduce portions of it should be sent to the Office of the Publisher at the address shown in the copyright notice above. The World Bank encourages dissemination of its work and will normally give permission promptly and, when the reproduction is for noncommercial purposes, without asking a fee. Permission to copy portions for classroom use is granted through the Copyright Clearance Center, Inc., Suite 910, 222 Rosewood Drive, Danvers, Massachusetts 01923, U.S.A.

The complete backlist of publications from the World Bank is shown in the annual Index of Publications, which contains an alphabetical title list (with full ordering information) and indexes of subjects, authors, and countries and regions. The latest edition is available free of charge from the Distribution Unit, Office of the Publisher, The WCrld Bank, 1818 H Street, N.W., Washington, D.C. 20433, U.S.A., or from Publications, The World Bark, 66, avenue d'Téna, 75116 Paris, France.

Robin Bates was with the Environment Department of the World Bank at the time this paper ivas prepared; he is now with the Industry and Energy Department. Janusz Cofala is with the Polish Academy of Sciences and the International Institute for Applied Systems Analysis. Michael Toman is with

Resources for the Future, Washington, D.C.

\section{Library of Congress Cataloging-in-Publication Data}

Bates, Robiı W.

Altemative policies for the control of air pollution in Poland /

Robin Bates, Janusz, Cofala, Michael Toman.

p. cm. - (World Bank environment paper ; no. 7)

Includes bibliographical references.

ISBN 0-8213-2753-4

1. Air pollution-Economic aspects-Poland-Forecasting. 2. Air

pollution-Economic aspects-Poland-Mathematical models.

3. Poland-Environmental conditions-Forecasting. I. Cofala,

Janusz. II. Toman, Michael A. III. Title. IV. Series.

HC340.3.Z9A43 1994

$363.73^{\prime} 926^{\prime} 09438-\mathrm{dc} 20$ 


\section{Table of Contents}

Abbreviations of Physical Units............................................................................... vi

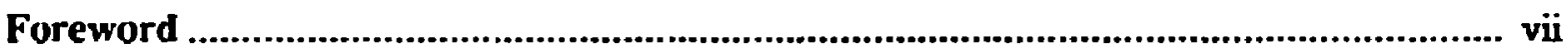

Acknowledgments ........................................................................................................... viii

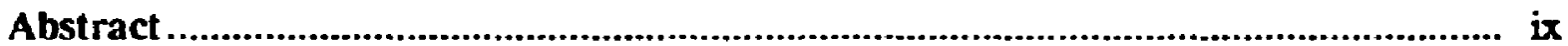

Chapter 1: Introduction .. .............................................................................................. 1

Background: Environment and Energy in Poland ............................................................... 2

Plan of the Study ............................................................................................................ 7

Chapter 2: Conceptual Background ...................................................................... 8

Measuring Emission Abatement Cost .................................................................................. 8

Command Versus Incentive-Based Policies................................................................... 8

Chapter 3: Analytical Framework.......................................................................... 14

Final Energy Demand Calculations ............................................................................. 14

Least-Cost Energy Supply ................................................................................... 16

Measuring Social Costs of Abatement ............................................................................ 18

Chapter 4: Design of Scenarios ............................................................................... 19

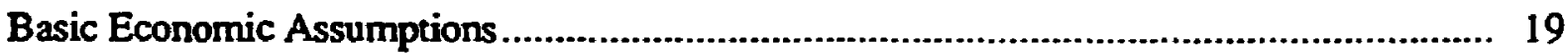

Altemative Emissions Standards ............................................................................ 20

Polish "Command-and-Control" Standards (CAC) .......................................... 20

European Community Standards (EEC) ......................................................... 21

German Standards (GER) ......................................................................... 21

Flat Rate Reductions (FRRED) .............................................................. 22

Comparison of Plant-Level Emission Standards ............................................... 22

Altemative Economic Instruments ......................................................................... 22

Uniform Emissions Taxes on Large Stationary Sources (ETAX1) ........................ 22

$\mathrm{SO}_{2}$ Trading by Large Sources (SO2TR)................................................... 23

Coal Tax (COALTX) ................................................................................ 23

Uniform Emissions Taxes on All Sources (ETAX2) ............................................ 23

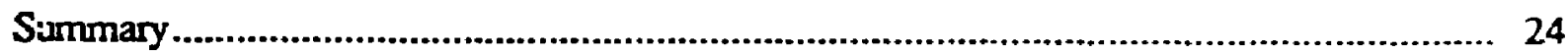


Base Case Scenario

Energy and Emissions Differences Across Standards Scenarios.

Energy and Emissions Differences Across Ecunomic Policy Scenarios ............................... 28

Economic Impacts of Emission Controls......................................................................... 29

Chapter 6: Institutional Issues ................................................................................ 36

Institutional Background ................................................................................................... 36

The Efiect of Restructuring on Economic Incentives ..................................................... 37

Considerations for Policy Evaluation .............................................................................. 39

Command and Control ................................................................................. 39

Emission Fees ..................................................................................................... 40

Emission Trading ................................................................................................... 42

Chapter 7: Concluding Remarks................................................................................. 46

Policy Consicierations ...................................................................................................... 47

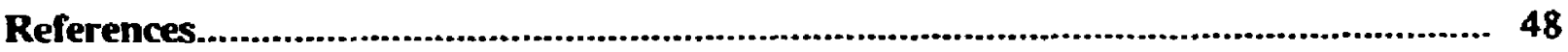

Appendices:

1. Details on the Modeling Scenario Definitions .................................................... 51

2. Details on the Model Results ........................................................................ 61

\section{Tables}

1.1 Ambient Environmental Standards in Poland, the U.S.A. and Germany .................. 3

1.2 Poland: Energy Intensity Compared with Selected Developed Countries ............... 5

1.3 Poland: Emissions Balances 1990............................................................................ 6

1.4 Poland: Emissions Intensity Compared with EC ..................................................... 6

4.1 Characteristics of Altemative Standards Scenarios ............................................... 25

4.2 Characteristics of CAC and Altemative Economic Instrument Scenarios ............... 26

5.1 Social Cost of Pollution Control, 1991-2015 (CAC) ......................................... 30

5.2 Social Cost of Pollution Control, 1991-2015 (Economic Instruments).................... 30

5.3 Energy Price Indices to Final Consumers for Scenarios ....................................... 33

5.4 Pollution Fees (Actual) and Taxes for ETAX1 and ETAX2 ............................... 34

5.5 Costs and Profits from Sulphur Dioxide Trading .................................................... 34

\section{Figures}

2.1 Social Costs of Emissions Controls ...................................................................... 9

2.2 Defining a Least-Cost Envelope of Abatement Strategies..................................... 11

2.3 Cost-Effective Distribution of Abatement Effort ................................................. 12 


\section{Appendix Tables}

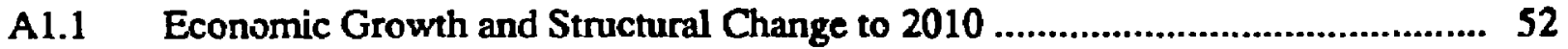

A1.2 Production of Energy-Intensive Products and Services................................... 52

A1.3 International Fuel Prices...................................................................... 53

A1.4 Fuel Prices to Final Energy Consumers in "BASE" Case ................................... 53

A1.5 Share of Transmission/Distribution Costs and Taxes in Fuel Prices to Final Consumers in 1995, the "BASE" Case................................................... 54

A1.6 Own Price Elasticities Applied in the Scenarios .............................................. 55

A1.7 Polish $\mathrm{SO}_{2}$ Standards .............................................................................. 55

A1.8 Polish $\mathrm{NO}_{\mathrm{X}}$ Standards ......................................................................... 56

A1.9 Polish Particulates Standards........................................................................ S6

A1.10 European Community $\mathrm{SO}_{2}$ Standards ...................................................... 57

A1.11 European Community $\mathrm{NO}_{\mathbf{X}}$ Standards....................................................... 57

A1.12 European Community Particulates Standards ................................................ 58

Al.13 German $\mathrm{SO}_{2}$ Standarćs........................................................................ 58

A1.14 German $\mathrm{NO}_{\mathrm{X}}$ Standards ........................................................................... 59

A1.15 German Particulates Standards.................................................................. 59

A2.1 Energy Demand and Energy Intensities for the "BASE" Scenario........................ 61

A.2.2 Changes in Sectoral Energy Intensities for the "BASE" Scenario....................... 61

A2.3 Emissions of Atmospheric Pollutants by Sectors, BASE Case .......................... 62

A2.4 Comparison of Scenario Results - Altemative Levels of Controls ....................... 63

A2.5 Emissions of Pollutants - Altemative Levels of Controls................................... 64

A2.6 Comparison of Scenario Results - Instruments for Large Stationary Sources ....... 65

A2.7 Emissions of Pollutants - Instruments for Large Stationary Sources ................... 66

A2.8 Comparison of Scenario Results - Tax on All Fuel Users................................... 67

A2.9 Emission of Pollutants - Tax on All Fuel Users.................................................. 68

A2.10 Comparison of Scenario Results - Coal Tax ................................................. 69

A2.11 Emission of Pollutants - Coal Tax ............................................................ 70

A2.12 Costs of Emission Control Measures for Large Stationary and Transport Sources 71

A2.13 Total Undiscounted Energy Supply and Conversion Investments......................... 71

A2.14 Production of Hard Coal and Lignite........................................................ 72 


\section{ABBREVIATIONS OF PHYSICAL UNITS}

kgoe $=$ kilograms of oil equivalent

MJ = megajoules

GJ = gigajoules

$\mathrm{PJ}=$ petajoules

$\mathbf{M W}_{\text {th }}=$ megawatts thermal energy

MWh = megawatthours

TWh = terawatthours

tce $=$ tonnes of coal equivalent

$\mu \mathrm{g} / \mathrm{m}^{3}=$ micrograms per cubic meter

$\mathrm{Nm}^{3}=$ normal cubic meters; refers to dry gas at $0^{\circ}$ Celcius and 1 atmosphere of pressure 


\section{FOREWORD}

The decade of the 1980 s wimessed a fundamental change in the way governments and development agencies think about environment and development. The two are no longer regarded as mutually exclusive. It is now recognized that a bealthy environment is essential to sustainable development and a healthy economy. Moreover, economists and planners are beginning to recognize that economic development that erodes natural capital is often not successful. In fact, development strategies and programs that $\mathrm{do}$ not take adequate account of the state of critical resources-forests, soils, grasslands, freshwater, coastal areas, and fisheries-may degrade the resource base upnn which future growth is dependent.

Since its creation, the Vice Presidency for Environmentally Sustainable Development (ESD) has placed the highest priority on the analysis of these important issues. Within ESD, the Environment Department's work in particular has focused on the links between environment and development and the implications of these links for development policy in general. The objective of the Environment Paper Series is to make the results of our work available to the general public.
The phrase "sustainable development" has been widely used, but we are still some way from a generally-recognized, operational definition of the concept. In particular, such a definition must be set in a usable analytical framework.

This paper attempts to show how appropriate economic incentives in the economy at large, and the use of specific economic instruments targeted at air pollutinn, can make an important practical contribution to sustainable development. The focus here is on the use of a common natural resource, namely the air we breathe, and ways in which it can be protecled.

The paper argues that, although free market forces alone may not achieve sustainable development. they can help us to make progress towards it through better resource management. Furthermore, the analysis and simulations presented in the paper suggest that by intervening in markets, especially energy markets, to allow for externalities, those same market forces can be hamessed to produce further environmental improvements. Besides other interventions, the paper considers systems of taxes and trading in property rights.
Mohamed T. El Ashry

Director

Environment Department 


\section{ACKNOWLEDGMENTS}

The simulation analysis presented in this study is the product of a team effort by numerous researchers at the Polish Academy of Sciences. The authors particularly wish to thank W. Bojarski, Z. Parczewski, A. Umer, Z. Klimont, and T. Mroczek for their contributions to the simulations.

A number of other Polish experts provided valuable support, information, advice, and comments during the course of the project. Wu owe a particular debt of gratitude to Stanislaw Simicki and Tomasz Zylicz in this regard. Jerzy Sleszynski provided useful information on Polish environmental policy. Within the Environment Ministry, we wish to thank Jerzy Kwiatkowsk:, Rafal Milaszewski, Wojciech Jaworski, and Jerzy Janota-Bzowski.

Winston Harrington (Resources for the Future) and Thomas Tietenberg (Colby College) provided in-depth and very useful comments on the manuscript. Helpful conversations and comments on the study also were received from Richard Ackemann, Gordon Hughes, Helmut Schreiber, and Mohan Munasinghe (World Bank) and from Dallas Burtraw (Resources for the Future). All conclusions and opinions expressed in the study are the authors' alone. We owe a further debt to Kay Murphy for her extensive efforts in preparing the manuscript.

The Polish consultants were financed by the World Bank and the Government of the Netherlands. Financial support for Toman's work was provided under a contract between Resources for the Future and the U.S. Environmental Protection Agency. 


\title{
ALTERNATIVE POLICIES FOR THE CONTROL OF AIR POLLUTION IN POLAND
}

\begin{abstract}
Like other Central European countries, Poland faces the twin challenges of improving environmental quality while also promoting econcmic development. This study examines the cost o: achieving altemative emission standards and the savings in abatement cost that might be achieved with policies that rely on economic incentives rather than with rigid "command and control" measures. The focus is prinarily on three pollutants arising from energy combustion-particulate matter (PM), nitrogen oxides $\left(\mathrm{NO}_{\mathrm{X}}\right)$, and sulphur dioxide $\left(\mathrm{SO}_{\mathrm{x}}\right)^{-}$although carbon dioxide $\left(\mathrm{CO}_{2}\right)$ emissions also are tracked. A central element of the analysis is a dynamic model of leastcost energy supply in Poland that allows examination at a narional level of the effects of different pollution standards and policies.

The simulation analysis suggests, first, that significant decreases in air pollution emissions seem likely from economic restructuring and energy pricing reforms and that tighter (enforced) emission standards such as those envisaged under current Polish policy are likely to generate considerable additional decreases in pollution. Second, the Polish legal standards differ in important respects from representative West European standards, but the costs of meeting the two altemarive sets of standards in Poland do not appear to be widely different. The costs of the strict German standards, on the other hand. are significantly higher, underscoring a need for corresponding benefit assessment to determine the value to Poland of such

standards. Third, there are clear cost savings from using incentive-based policy instruments, even though the exact size of the savings cannot be precisely identified. Finally, the impacts on invesument and energy prices of environmental policies are likely to be dwarfed by the forces of economic restrucnuring and energy price reform.

The analysis also suggests a dynamic and mixed sxategy for the impiementation of economic instruments. Starting with command and control, emission fees could be increased to encourage some additional abatement and technical innovation and to provided added revenues to be used, e.g., for cleanup of existing environmental damages. However, it is unilkely that fees can be increased to th: : level necessary to meet current emissions standards. To accomplish this goal cost-effectively, an evolurionary movement toward emissions trading should be considered. Trading could start with informal bilateral transactions, as in the US, and become more extensive as circumstances and the interests of polluters warrant. However, even limited emissions rrading would require clearer legal and regulatory authority, as well as continued progress in economic restructuring. We further emphasize the importance of continued progress in economic and energy price reform as both a complement to and a prerequisite for success in environmental policy, so that firms have incentives to seek out lower-cost abatement options.
\end{abstract}




\section{Chapter 1}

\section{INTRODUCTION}

Like other Central European countries, Poland faces the twin challenges of improving environmental quality while also promoting economic development. Pollution, especially in the air, poses serious threats to human health and other resources in many parts of the country, though the precise extent of the hazards remains controversial. At the same time, excessive expenditure on pollution mitigation must be avoided, given a scarcity of capital needed for raising living standards.

This study examines two broad issues related to the design of air pollution policy in Poland. The first issue is the cost of achieving altemative emission standards that are of potential interest for Polish environmental policy. The second issue is the savings in abatement cost that might be achieved if a particular set of standards is implemented with policies that rely on economic incentive:-particularly taxes on emissions or tradable emission permitsrather than with rigid "command and control" (CAC) measures. In this analysis the emission standards themselves are taken as given rather than being inferred from a broader study of pollution damages and abatement costs.

The rocus is primarily on pollutants arising from energy combustion-particulate matter (PM), nitrogen oxides $\left(\mathrm{NO}_{\mathrm{X}}\right)$, and sulphur dioxide $\left(\mathrm{SO}_{2}\right){ }^{1}$ Carbon dioxide $\left(\mathrm{CO}_{2}\right)$ emissions also are tracked. A central element of the analysis is a dynamic model of least-cost energy supply in Poland. The model, developed at the Polish Academy of Sciences, allows examination at a national

\footnotetext{
${ }^{1}$ Emissions from industrial processes (e.g., cement manufacturing) also are included, though they are a very small part of the total.
}

level of the effects of different pollution standards and policies. The simulations provide considerable disaggregation by type of fuel and sector. With these model outputs we can calculate the costs of different emission standards and of different policies to attain specified standards over the next 25 years.

The model deals only with categories of emitters and generic categories of emission standards rather than specifying the size, spatial location, and emissions standards of specific sources. Consequently, the model cannot be used to analyze the cost of different ambient air quality standards or the cost of different means for achieving specified ambient standards: our policy simulations ignore ambient air quality constraints and focus only on the achievement of emission standards. This is an important drawback, both from a practical perspective (Polish regulations include ambient as well as emissions standards) and an analytical perspective (the design of cost-effective regulation is complicated by the need to meet ambient standards as well as emission standards). The model also takes as given broad trends in the composition and energy intensity of economic activity; it does not describe the process of economic restructuring itself. Two studies now under way by the World Bank are designed to address these gaps. The furst, financed in part by the U.K. Environmental Know How Fund, is extending the analysis of altemative policy instruments to a local level, by examining air pollution and environmental management in the Krakow region. Air dispersion modeling provides the link between emissions and ambient standards. The second, assisted by Norwegian financing, is considering how 
Poland is restructuring economic incentives in general and analyzing the impact on the energy sector and air pollution in particular.

Subject to these caveats, the simulation analysis provides estimates of the potential gains from relying upon incentive-based policies over CAC for meeting emission targets. Even in advanced industrial economies, not all this potential will be reached, because of imperfections in markets and policies. A prominent example of market distortions is imperfect regulation of the electric power sector. Environmental policies may also depart from the ideal to achieve compromises with equity or other social goals. Problems of this type are multiplied in transitional economies like Poland's, in which market institutions are still evolving, the state continues to play a substantial role in the economy, and social goals are not clearly defined and in flux.

To address these points we include some discussion of how environmental policies are carried out in Poland and of implementation problems under transitional circumstances. However, we give no quantitative estimate of how institutional and social constraints might cause environmental policies to fall short of their theoretical potential; nor do we exhaust all the institutional and policy issues amenable to qualitative analysis. This area is at or near the forefront of research in environmental economics and is ripe for further research. In particular, analysis of how altemative means of restructuring and managing the power sector might affect economic performance and environmental quality deserves a high priority.

\section{BACKGROUND: ENVIRONMENT AND ENERGY IN POLAND}

Poland suffers from the disastrous environmental legacy of central planning: in
1983-89, it was the third largest emitter of $\mathrm{SO}_{2}$ and $\mathrm{NO}_{x}$ in Europe, after the former Soviet Union and Germany; with regard to PM, it ranked second (Nowicki 1993); and $\mathrm{SO}_{2}$ and $\mathrm{NO}_{\mathrm{x}}$ emissior per US $\$$ of GNP were the hightst among all countries of Central and Eastern Europe, including the former Soviet Union (World Resources Institute 1992). One of the characteristics of air pollution in Poland is that the sources of emissions are heavily concentrated. In Katowice and Krakow, two of the most polluted regions, emissions of dust and gases in 1990 were 5-9 times and 10-12 times the national average per unit land area respectively (Central Statistical Office 1991, Table II). In consequence, a disproportionate number of people in these regions is affected by air pollution.

Upper Silesia, which contains the Katowice region, has orily 10 percent of the nation's population and 2 percent of its land area, but it is responsible for about one-third of all $\mathrm{SO}_{2}$ and PM emissions, and one-fifth of $\mathrm{NO}_{\mathrm{x}}$ emissions (Nowicki 1992, p. 12). Katowice is home to 22 of the 80 most polluting enterprises in Poland. As a result, in 1989 the annual average concentrations of $\mathrm{SO}_{2}$ and $\mathrm{NO}_{\mathrm{x}}$ in the Katowice region exceeded the permissible standards by a factor of two while PM exceeded standards by a factor of four (Coopers \& Lybrand Deloitte 1991, Tables 2.7-2.9)—well beyond the guidelines proposed by WHO. The permissible annual average concentration in Poland for $\mathrm{SO}_{2}$ is $32 \mu \mathrm{g} / \mathrm{m}^{3}$, and for $\mathrm{NO}_{\mathrm{X}}$ and $P M$ it is $50 \mu \mathrm{g} / \mathrm{m}^{3}$. The WHO guidelines suggest upper limits for $\mathrm{SO}_{2}$ and $\mathrm{PM}$ of 60 $\mu \mathrm{g} / \mathrm{m}^{3}$ and $90 \mu \mathrm{g} / \mathrm{m}^{3}$, respectively (United Nations Environment Program 1992).

Table 1.1 compares ambient air quality standards in Poland with the US and Germany. The comparison makes clear that the Polish standards are significantly tougher than comparable Westem figures. 
Table 1.1. Ambient Environmental Standards in Poland, the U.S.A. and Germany $\left(\mu \mathrm{g} / \mathrm{m}^{3}\right)$

\begin{tabular}{|l|c|c|c|c|c|c|}
\hline & \multicolumn{2}{|c|}{ Poland } & \multicolumn{2}{c|}{ U.S.A. } & \multicolumn{2}{c|}{ Germany } \\
\hline Pollutant & $\begin{array}{c}24 \text { hrs. } \\
\text { average. }\end{array}$ & $\begin{array}{c}\text { annual } \\
\text { average }\end{array}$ & $\begin{array}{c}24 \mathrm{hrs} . \\
\text { average }\end{array}$ & $\begin{array}{c}\text { annual } \\
\text { average }\end{array}$ & $\begin{array}{c}24 \mathrm{hrs.} \\
\text { average }\end{array}$ & $\begin{array}{c}\text { annual } \\
\text { average }\end{array}$ \\
\hline $\mathrm{SO}_{2}$ & $200 \mathrm{~d} /$ & 32 & 365 & 80 & $-. \mathrm{b} /$ & 140 \\
$\mathrm{NO}_{2}$ & 150 & 50 & - & 100 &.- & 80 \\
$\mathrm{PM}$ & 120 & 50 & 150 & 50 & $-\mathrm{b} /$ & 150 \\
\hline
\end{tabular}

$\mathbf{a} / 150$ after 1998.

b/German standards for these pollutants are stated in terms of the 98th percentile of the average over any $30-$ minute period. The figures for $\mathrm{SO}_{2}$ and $\mathrm{PM}$ are 400 and 300 respectively. The comparable sulphur figure for Poland is 600 (440 after 1998).

Sources: Polish figures are taken from the Ordinance of the Ministry of Environmental Protection, Natural Resources and Forestry on the Protection of Air Against Pollution, 12 February 1990. U.S. and German figures are based on calculations by Mr. Shakeb Afsah, World Bank, drawing in part on Cochran and Pielke (1992). 
Nevertheless, the limited available evidence (including parallel studies under the World Bank's Environmental Action Programme for Central and Eastem Europe) suggests that ambient conditions have imposed important burdens on human health, particularly in Upper Silesia and Krakow. ${ }^{2}$ The non-health impacts also are thought by many to be significant, though their actual severity is subject to dispute.

Severe smog conditions and high sulphur concentrations in Krakow, the old capital of Poland, have had a serious impact on the city's residents as well as valuable historic buildings and monuments. In 1990, the Krakow region was the second most polluted in Poland, next to Katowice (Central Statistical Office 1991, Table II). It experiences smog incidents more than any other city in Poland, with $\mathrm{SO}_{2}$ concentrations reaching $3000-4000 \mu \mathrm{g} / \mathrm{m}^{3}$ ( Nowicki 1992, p. 16). In 1989, the average ambient concentration of $\mathrm{SO}_{2}$ in Krakow was 70 $\mu \mathrm{g} / \mathrm{m}^{3}$ (Coopers \& Lybrand Deloitte 1991), more than twice the national standard; and the annual average concentration of PM (62 $\mu \mathrm{g} / \mathrm{m}^{3}$ ) also exceeded the national standard. Similarly, in 1989 the maxirium daily concentrations exceeded the permitted amounts by a factor of two (Coopers \& Lybrand Deloitte 1991, Tables 2.10-2.13). However, it should be noted that emissions from the main polluters in Krakow have recently dropped, due in no small measure to the restructuring of the local industrial base, and ambient air quality has improved since 1987. Average concentrations of $\mathrm{SO}_{2}$ and PM in 1991 fell to $67 \mu \mathrm{g} / \mathrm{m}^{3}$ and $54 \mu \mathrm{g} / \mathrm{m}^{3}$ respectively (Bolek and Wertz 1992). Problems from $\mathrm{NO}_{\mathrm{X}}$ are believed to be less serious than with $\mathrm{SO}_{2}$ and $\mathrm{PM}$, although the very limited data which are available point to

2See in particule; Krupnick, Harrison, Nickell, and Toman (1993). daily concentrations well in excess of the permitted amounts (Coopers \& Lybrand Deloitte 1991, Tables 2.10-2.13); and particular problems are created in the older parts of the city of Krakow (Ministry of Environmental Protection 1991).

Air pollution in Poland is predominantly caused by energy production and use, especially coal. Estimates of the precise extent of energy's contribution vary, party no doubt due to differences in definition. However, according to estimates made in this study (Appendix 2, Table A2.3), energy production and use in 1990 by large stationary sources, essentially for electric power generation and hear production. accounted for 70-80 percent of the emissions of $\mathrm{PM}$ and $\mathrm{SO}_{2}$, and nearly 50 percent of the emissions of $\mathrm{NO}_{\mathbf{x}}$. The Ministry of Environmental Protection, Natural Resources and Forestry estimated that the energy sector was responsible for 90 percent of $\mathrm{SO}_{2}$ emissions, and 60-70 percent of dusts and $\mathrm{NO}_{\mathbf{X}}$ (Ministry of Environmental Protection 1991, p. 13). Using 1987 data, Sierpinska (1991, p. 28) attributes 54 percent of dust and 55 percent of gas emissions to the fuel and power industry; while Wasikiewicz (1991, p. 111), with 1988 data, shows 66 percent of $\mathrm{SO}_{2}, 42$ percent of $\mathrm{NO}_{x}$ and 27 percent of dust coming from energy production. Aside from being the main source of air pollution in Poland, energy provides most ( 80 percent in 1988) of the enissions of carbon dioxide (Nowicki 1992. p. 6).

An important underlying cause of energy's role in air pollution is the fact that Poland has one of the most energy-intensive economies in the world, with heavy dependence on coal and lignite. According to World Bank data, in 1989 Poland's energy intensity was 1.889 kgoe per US\$ of GDP (at 1987 prices), exceeded only by China at 1.915 (Bates and Moore 1992). Using a 
slightly different measure, the World Resources Institute put Poland in first place, with $79 \mathrm{MJ}$ per US\$ of GNP (at 1987 prices), and China second with 76 MJ per US\$ of GNP (World Resources Institute 1992, Table 21.2). Of particular significance is the fact that Poland's total primary energy requirement per US $\$$ of GDP is about twice as much as the average for Westem Europe (International Energy Agency 1990, p. 11). Comparisons with selected developed countries are even less favorable, as shown in Table 1.2.

Although the above figures are admittedly crude indicators of energy intensity, there seems to be little doubt that there has been an underlying structural element to Poland's air pollution problem. This is aggravated by the fact that the Polish economy is not only energy intensive, but also coal-intensive. Hard coal and brown coal (lignite) supplied 78 percent of total primary energy requirements in 1991, compared with
12 percent for oil, 9 percent for gas and 1 percent for other fuels (Central Statistical Gffice 1992). Among the larger economies, only South Africa was more dependent on coal for its primary energy supply in 1989, although Bulgaria, North Korea and Czechoslovakia were similar (World Resources Institute 1992-3, Table 21.1). Coal consumption is particularly concentrated in specific sectors, one of which is electricity, which depended on coal for 96 percent of its generation in 1989 (60 percent from hard coal and 36 percent from lignite). Electricity and heat production together accounted for more than half the Polish coal market in 1989 (Intemational Energy Agency 1990, p. 162). In consequence, within the energy sector coal contributes 82 percent of PM, 90 percent of $\mathrm{SO}_{2}, 46$ percent of $\mathrm{NO}_{x}$, and 75 percent of $\mathrm{CO}_{2}$ (see Table 1.3). It is not surprising that the emissions intensity of the Polish economy is so much higher than that of the US and the EC (Table 1.4).

Table 1.2. Poland: Energy Intensity Compared with Selected Developed Countries (kgoe/US\$ GDP at 1987 prices)

\begin{tabular}{|l|l|l|l|}
\hline Country & 1982 & 1987 & 1989 \\
\hline & & & \\
Poland & 2.272 & 1.995 & 1.889 \\
France & 0.232 & 0.234 & 0.223 \\
Germany & 0.254 & 0.248 & 0.223 \\
Japan & 0.175 & 0.166 & 0.163 \\
United Kingdom & 0.342 & 0.317 & 0.288 \\
United States & 0.457 & 0.394 & 0.406 \\
& & & \\
\hline
\end{tabular}

Source: Bates and Moore (1992), p. 43. 
Table 1.3. Poland: Emissions Balances 1990

\begin{tabular}{|l|r|r|r|r|r|r|r|r|}
\hline \multirow{3}{*}{ Source } & \multicolumn{2}{|c|}{$\mathrm{SO}_{2}$} & \multicolumn{2}{c|}{$\mathrm{PM}$} & \multicolumn{2}{c|}{$\mathrm{NO}_{x}$} & \multicolumn{2}{c|}{$\mathrm{CO}_{2}$} \\
\cline { 2 - 9 } & $\begin{array}{r}10^{3} \\
\text { tonnes }\end{array}$ & $\%$ & $\begin{array}{c}10^{3} \\
\text { tonnes }\end{array}$ & $\%$ & $\begin{array}{c}10^{3} \\
\text { tonnes }\end{array}$ & $\%$ & $\begin{array}{c}10^{3} \\
\text { tonnes }\end{array}$ & $\%$ \\
\hline Coal \& lignite & 2.542 .9 & 90 & $1,205.8$ & 82 & 547.22 & 46 & 271,823 & 75 \\
\hline $\begin{array}{l}\text { Petroleum } \\
\text { products }\end{array}$ & 175.6 & 6 & 25.1 & 2 & 477.65 & 40 & 38,886 & 11 \\
\hline Natural Gas & - & - & - & - & 31.14 & 3 & 20,433 & 5 \\
\hline Process Emissions & 97.8 & 3 & 233.1 & 16 & 82.15 & 7 & 6,250 & 2 \\
\hline Other & 16.2 & 1 & 4.0 & & 49.43 & 4 & 26,185 & 7 \\
\hline Total & $2,832.5$ & 100 & $1,468.0$ & 100 & $1,187.59$ & 100 & 363,577 & 100 \\
\hline
\end{tabular}

Table 1.4. Poland: Emissions Intensity Compared with EC (Tonnes/US\$millions of GDP) (1989)

\begin{tabular}{|c|c|c|c|}
\hline Emission: & Poland & U.S. & EC \\
\hline & & & \\
$\mathrm{SO}_{2}$ & 58.4 & 4.0 & 2.6 \\
$\mathrm{NO}_{\mathrm{x}}$ & 22.1 & 3.8 & 2.2 \\
$\mathrm{CO}_{2}$ & 1,872 & - & 170 \\
\hline
\end{tabular}

Source: World Resources Institute (1992), Tables 5.2 and 5.4; and Intemational Energy Agency (1990). 
At present, vehicles (mobile sources) contribute less to total emissions than do coal buming and industrial processes, probably due to the fact that vehicle ownership is still relatively low in Poland (138 passenger cars per thousand population in 1990, compared with 410 in France and 360 in the Netherlands). Even so, vehicles contribute over 30 percent of $\mathrm{NO}_{\mathrm{X}}$ emissions, 37 percent of carbon monoxide, 24 percent of hydrocarbons, and 35 percent of lead (Nowicki 1992, p. 22; Wasikiewicz 1991, p. 111). They also are probably more significant for ambient air quality than these emissions percentages suggest, since vehicle emissions are concentrated in areas of high population density, such as the center of Krakow, where serious constraints are imposed on traffic planning by the configuration of the old city. Emissions from mobile sources are likely to increase, as the growth rate of passenger vehicle ownership is high: 7.5 percent per annum in Poland over the period 1980-1990, compared with 1.6 percent per annum in France. According to the results of this study, the number of private cars will reach
6.8 million by 2000 ( 172 per thousand population) and 8.8 million ( 215 per thousand population), compared with 5.3 million in 1990. However, the growth in emissions also depends on changes in the types and age distribution of vehicles, as well as on policies designed to reduce emissions, although such changes in the vehicle stock are expected to have a dampening effect on emissions. ${ }^{3}$

\section{PLAN OF THE STUDY}

Chapter 2 provides a brief conceptual introduction to the measurement of emission abatement cost and the differences between command-and-control policies and policies relying upon economic incentives. Chapter 3 provides an introduction to the simulation framework, while Chapter 4 describes the scenarios we consider. Chapter 5 reports results of the simulation analysis. In Chapter 6 we discuss institutional and other practical issues that arise in selecting policy options in Poland. Chapter 7 briefly summarizes our conclusions.

\footnotetext{
${ }^{3}$ See Walls (1993) for further discussion. Note also that even with the projected growth in Polish vehicle ownership, the number of cars per capita will be well below Western European experience.
} 


\section{Chapter 2}

\section{CONCEPTUAL BACKGROUND}

Since a central focus in this study is assessing the economic cost of emission reduction in different scenarios, we first define what is encompassed in the full social cost of emission reduction. We then discuss the potential differences in cost that may arise with incentive-based policies compared to command and control.

\section{MEASURING EMISSION ABATEMENT COST}

The most obvious source of cost in reducing emissions is expenditures on control equipment and effort. In the context oi air pollution from energy combustion these expenditures include investments in direct pollution control equipment (such as catalytic converters and devices for flue gas desulphurization); fuel switching or fuel quality improvement (coal washing); and any additional cost of investment in energy conversion technologies that give rise to lower emissions (such as advanced coal combustion systems for electricity generation). Resources invested in these activities are not available for other purposes and thus constitute part of the opportunity cost of pollution control.

There also are indirect effects of policy that may be important. These arise from the fact that, at least in a functioning market system, the additional costs of pollution control will be reflected in higher prices for final goods and services. As a result, consumers will reduce consumption of more expensive cornmodities and experience a loss in real well-being; in effect, the real command of household incomes over goods and services will be reduced. Reduced demands also will lower rents eamed by limited factors of production (producer surplus).

Figure 2.1 illustrates these effects in a simple setting with only one final good, which we can take to be total energy services. The curves $S^{0}$ and $S^{1}$ represent the supply of energy services before and after the imposition of stricter pollution standards. The demand for energy services is represented by $D$. With the stricter standarcs, and assuming that price clears the market for energy services, the price increases from $\mathrm{P}^{0}$ to $\mathbf{P}^{1}$ and consumption correspondingly declines from $Q^{0}$ to $Q^{1}$. Area $A$ in the diagram represents the cost of compliance with tighter standards given the reduced use of energy services. Areas B and C represent losses in consumer and producer surplus respectively from the induced drop in energy services use. The procedures used for calculating the analogues of Areas A, B, and $C$ in the simulation model of least-cost energy use are discussed in Chapter 3.

\section{COMMAND VERSUS INCENTIVE- BASED POLICIES 4}

Associated with each technology capable of reducing emissions of a particular pollutant is a marginal cost curve that indicates the incremental cost of emission reduction using that technology. The incremental cost of emission reduction for society as a whole depends not just on the costs of individual technologies but also on the rules goveming how technologies can be used. In particular, the incremental cost to society is likely to be

${ }^{4}$ For further discussion of the ropics in this section see, e.g., Pearce and Tumer (1990) and Tietenberg (1992). 


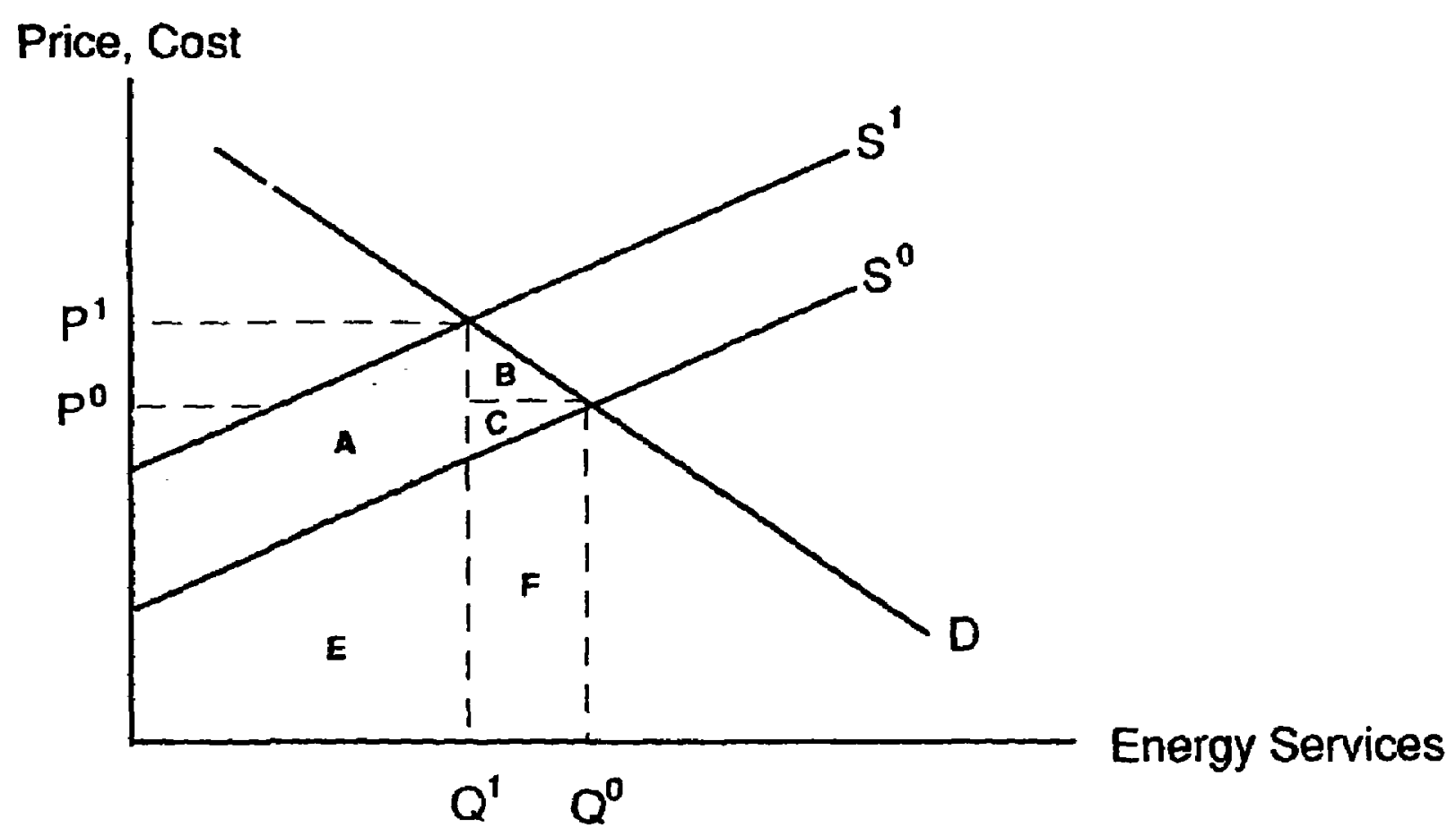

Figure 2.1. Social Costs of Emissions Control 
different when command-and-control policies stipulate actions by polluters compared to policies that rely upon economic incentives, such as taxes on emissions or tradable emission permits.

These points are illustrated in Figures 2.2 and 2.3. Figure 2.2 shows the construction of a least-cost marginal cost curve (MACagg) from marginal cost schedules for different abaiement technologies (MAC $1 \mathrm{MAC}^{2}, \mathrm{MAC}^{3}$ ). The least-cost deployment of technologies is achieved by successively exhausting all lowercost efforts, across all technologies, before undertaking higher-cost efforts. This is the "lower envelope" of the constituent costs of different technologies shown.

This also is the outcome that will obtain ideally when polluters face economic incentives to reduce emissions without constraints on the means of compliance. Under these conditions, polluters naturally will seek out the least costly control strategies in order to minimize total costs of economic activities, including the costs of meeting emission limits. If, instead, policy dictates the use of a particular technology as the "best practicable," then the marginal cost of abatement becomes the marginal cost associated with the identified technology. In this case some lower-cost options generally will be foregone, and the overall marginal cost of abatement will be increased by the policy constraint. ${ }^{3}$

Policy also can raise the overall marginal cost of emission abatement by prescribing a distribution of abatement effort

\footnotetext{
In many cases, required technologies are not actually specified in law, but polluters are required to show that they have achieved emissions reductions at least as large as those obtained with some specified technologies. Under such circumstances, polluters often are drawn in practice to the reference tectnologies unless other options are much cheaper, if only to avoid the extra burden of proof that comes with deviating from the benchmark control strategies.
}

across polluters, even if specific abatement rechnologies are not required. This is shown in Figure 2.3. Suppose that two polluters have different costs of abatement because of basic differences in their technologies. Their marginal costs are indicated by $\mathrm{MAC}^{\mathrm{A}}$ and $M A C^{B}$ in the figure. Suppose that the total amount of abatement required to be undertaken by $A$ and $B$ is indicated by the length of the horizontal axis in the figure. The total cost of abatement by $A$ and $B$ is minimized by the distribution of effort where $\mathrm{MAC}^{\mathrm{A}}=\mathrm{MAC}^{\mathrm{B}}$. For any other distribution of effor, total cost could be lowered by shifting responsibility away from the polluter with higher MAC toward the polluter with lower MAC.

The outcome with $\mathrm{MAC}^{\mathrm{A}}=\mathrm{MAC}^{\mathrm{B}}$ is the one that will be achieved (at least approximately) with incentive-based policies for emission reduction. With an emission tax, emitters will only reduce discharges if the marginal cost of doing so is less than the tax: given a common tax across emitters, marginal abatement cost will be equalized at the level of the tax. With errission permit trading, polluters will be indifferent between reducing emissions and transacting in permits, when the price of permits equals the marginal cost of emission abatement for all firms. Again, marginal costs are equalized at the (common) value of the price of permits. In contrast, a specified distribution of emission reduction effort under command and control is likely to raise total cost relative to the outcome with more flexible incentive-based policies. ${ }^{6}$

\footnotetext{
${ }^{6}$ Our focus here is on emission control. However, the ultimate goal of pollution control is improving ambient air quality. When pollutants do not mix uniformly in the atmosphere, location of emissions matters in determining the effect of different emission reductions on air quality. This is true in varying degrees for all the pollutants we consider. As pointed out in Chapter 6, this considerably complicates the design of effective policy.
} 


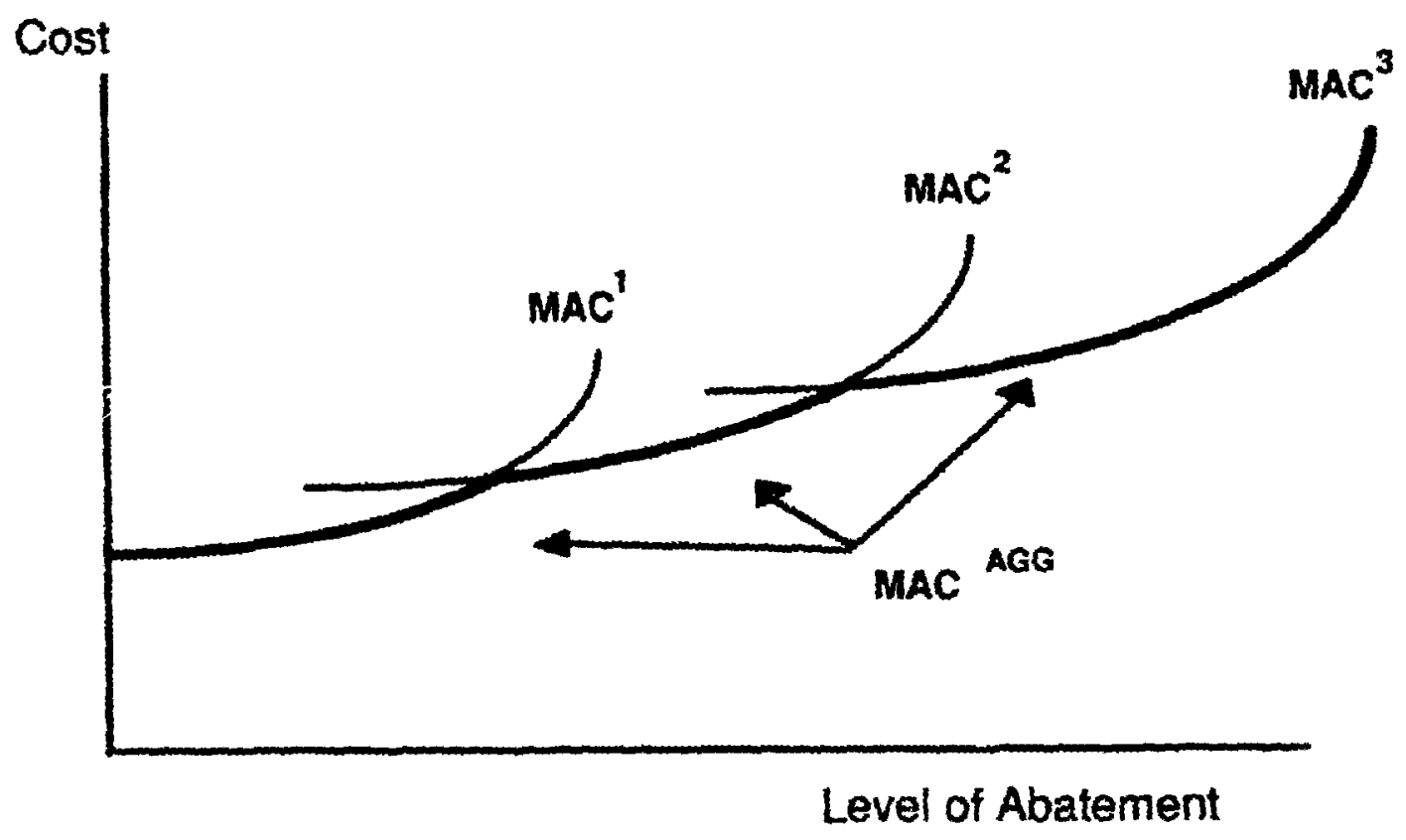

Figure 2.2 Defining a Least-Cost Envelope of Abatement Strategies 
Cost for A

Cost for B

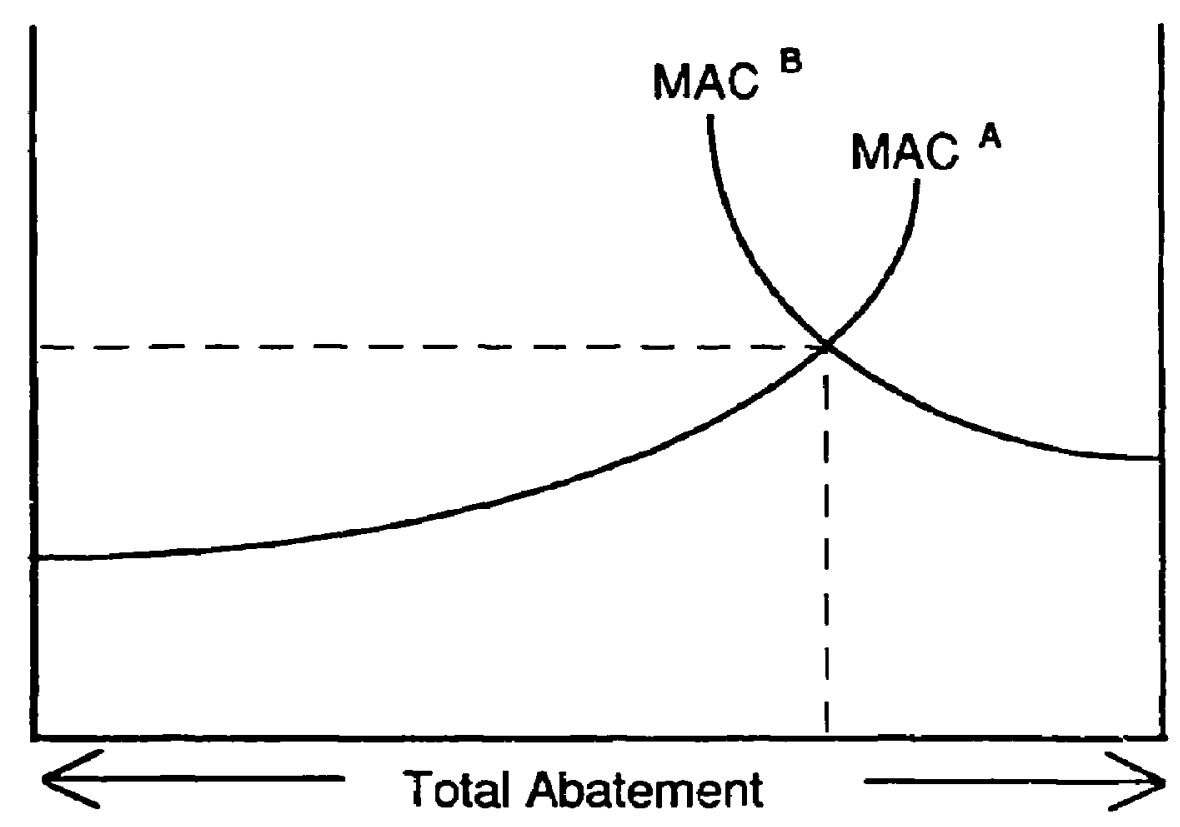

Abatement by $\mathrm{A} \longrightarrow$ Abatement by $B$

Figure 2.3 Cost-Effective Distribution of Abatement Effort 
In addition to static efficiency gains, incentive-based policies convey dynamic benefits by rewarding the introduction of lower-cost pollution abatement technologies. Such technical progress allows polluters to expand abatement in cost-effective ways and reduce permit purchases or increase permit supplies. With emission charges, lower abatement cost allows polluters to reduce costs by engaging in more abatement effort, in order to avoid the tax. In contrast, rigid approaches provide little incentive for technical innovation, particularly when the controls specify the means for abatement. 


\section{Chapter 3}

\section{ANAL YTICAL FRAMEWORK}

Analyzing the effects of policies to control energy-related air pollution requires a description of energy service demands and the ways those demands are satisfied. Total pollution discharges will reflect the total demands for different energy types and the ways in which energy services are provided. We first describe the process of determining time paths of final energy demands in the simulations. The second part of the chapter describes the simulation of least-cost energy supply decisions. We conclude by retuming to the issue of how the social cost of abatement can be measured using the outputs of the model.

\section{FINAL ENERGY DEMAND Calculations}

Total final energy demand in the economy ultimately depends on the level of economic activities in different sectors and the energy intensities of these activities. Energy intensities will vary across altemative technologies that can be used to accomplish the economic activities under consideration. Projection of final energy demands requires projection of all these component influences.

To express these ideas more formally, suppose the economy is divided into $\mathrm{j}=1, \ldots$, J sectors. Within each sector $j$ there are $k=$ $1, \ldots, K_{j}$ activities, each involving some energy use. Suppose further that each activity $k$ can be pursued through the use of $\mathrm{m}=1, \ldots, \mathrm{M}_{\mathrm{k}}$ technologies. Finally, suppose each technology uses some subset of final energy types $i=1, \ldots, I$.

\footnotetext{
${ }^{7}$ Additional discussion of the model can be found in Cofala (1985) and Cofala et al (1990).
}

define:

Using these indexing conventions,

$A_{k j}=$ level of activity $\mathrm{k}$ in sector $\mathrm{j}$;

$T_{m k j}=$ share of $A_{k j}$ achieved with technology $\mathrm{m}$;

$F_{m k j}=$ energy intensity of technology $m$ in pursuing $A_{k j}$;

$S_{i m k j}=$ share of final energy type i used with technology $m$ in pursuing $A_{k j}$.

An example may be useful in interpreting these symbols. Suppose $\mathrm{j}=$ ferrous metallurgy, and $\mathbf{A}_{\mathbf{k j}}=$ basic steel output measured in tonnes (as opposed to, say, rolled products using basic ingots as an input). The technology index $m$ refers to different technologies for ingot production (oxygen furnace versus open hearth), so the $T_{\text {mkj }}$ are the shares of total ingot output produced by different technologies and $F_{\text {mkj }}$ are the energy intensities of the processes. The $T_{\text {mkj }}$ are pure numbers between zero and one, while the $F_{\text {mkj }}$ reflect energy applied per unit output (e.g., PJ/tonne). The $S_{\text {inkj }}$ are the shares of different final energy types per unit of total energy application in the processes (e.g., PJ of coal, gas, or electricity per PJ total energy input). Another example can be given in terms of transport, where the $A_{k j}$ represent different levels of transport activities, the $T_{\text {mkj }}$ represent different vehicle types or modes, and the $F_{m k j}$ represent fuel efficiencies.

With this notation, the following energy quantities can be defined:

$\begin{aligned} E_{i m k j}= & \text { total amount of energy type i used by } \\ & \text { technology } \mathrm{m} \text { for activity } \mathrm{k} \text { in sector } \mathrm{j}\end{aligned}$ 


$$
=A_{k j} T_{m k j} F_{m k j} S_{i m k j}
$$

$E_{i j} \quad=\underset{i}{ }$ total sector $\mathrm{j}$ demand for energy type

$$
=\sum_{k=1 m=1}^{K_{j}} \sum_{k}^{M_{k}} E_{i m k j}
$$

$E_{i} \quad=$ aggregate demand for energy type $\mathrm{i}$

$$
=\sum_{j=1}^{J} E_{i j}
$$

$E j=$ total energy demand in sector $\mathrm{j}$

$$
=\sum_{i=1}^{I} E_{i j}
$$

Note that a time subscript has been suppressed in this formulation. In practice, all the components of final energy use will vary over time. Economic activity and technology choices in the industry, transport and other sectors will change in response to general economic restructuring and increased energy prices. Fuel choices and energy intensity similarly will respond to changing economic incentives-in particular to incentives for energy conservation.

To operationalize this framework requires projecting each component in equatior (3.1) over time, which is done here in two steps. The first step is projecting energy-using activity levels in the economy (the $A_{k j}$ ). Projecting these activities requires the analyst to take a view on how the entire structure of the Polish economy will evolve. In principle, this could be done with a dynamic general equilibrium model that included investment behavior, trade linkages, and macroeconomic effects. However, such a framework is daunting even for an advanced industrial economy. It is almost inconceivable for a transitional economy.

Thus, we have been forced to rely upon more heuristic projections of the composition of Polish economic activity, prepared by a variety of sectoral experts consulted by members of our research team from the Polish Academy. These compositional projections are combined with World Bank macroeconomic forecasts and other judgments to develop the $A_{k j}$. Starting with a base year of 1990 , projections are made at five-year intervals to 2015.

Similar problems arise in projecting choices of energy-using technologies, choices of fuel types, and trends in energy intensity. Technology and fuel type shares are specified heuristically using sector experts' judgments. Base Case energy intensities and thus total energy requirements also are calculared in this way (the Base Case is described funther in the next chapter). The expert judgments include assessments of how the size and composition of energy demand will respond to higher energy prices and economic restructuring. No effort is made to link changes over time in Base Case energy demands to assumed energy price trends and simple (point) elasticities, out of fear that such calcularions would give misleading or implausible answers in light of the large energy price increases Poland has faced and the massive change in the structure of energy use that is occurring. Past experience provides little guidance in assessing these changes given the size of the price increases and the fact that conventional market responses did not operate in Poland in the past.

On the other hand, our approach to calculating Base Case energy demands has a potentially serious drawback in the policy scenarios. As noted in Chapter 2, one element of the social cost of abatement is the reduction in consumer surplus when abatement expenditures raise the price of 
energy services and other commodities. Without some allowance for a response of energy demands to higher prices, the capability to include this effect in the social abatement cost calculation is lost.

To ameliorate this problem, in the policy scenarios we adjust energy demands relative to the Base Case by using a set of simple own-price elasticity assumptions for broad energy categorie', along with estimates of delivered price, increases reflecting abatement costs, pollution charges, or prices for traded permits bome by energy service suppliers. In light of significant uncertainties about cross-price effects, we make no effort to include them. The demand adjustment is made iteratively. First, energy supply costs are calculared under a policy scenario with the Base Case demands. The calculated increases in delivered energy costs over the Base Case are used with the elasticities to adjust demands. Then the new demands are used to rerun the energy supply module described below. In practice, only one or two iterations are needed to get convergence. ${ }^{8}$

Along with projecting final energy demands, this part of the analytical framework keeps track of air emissions from final energy use in different economic activities. (Emissions from energy conversion are tracked in the optimization part of the model described below.) In many cases, emissions follow directly from the quantity and type of fuel used. In other cases, however, emissions depend on the process used as well as the fuel. For example, sulphur from fuel may be absorbed in cement production, while additional sulphu beyond that in fuel may be released in copper production. In these cases, process emission

\footnotetext{
${ }^{8}$ As described in the next chapter, the iteration process is more intricare when demands must be adjusted to reflect delivered cost increases and emission charges must be adjusted to satisfy specified emission targets.
}

factors are used to express emissions as a function of total activity.

Process emission factors for $\mathrm{SO}_{2}$ and $\mathrm{NO}_{x}$ are used to describe emissions from production of agglomerate, pig iron, raw steel (from open hearth and oxygen fumaces), copper, cement, nitric acid, and nitrogenous fertilizers. Process emission factors also are used for keeping track of particulates, since PM emissions depend on how coal is combusted. Emissions from the transport sector also vary across the policy scenarios, given different assumptions about the imposition of control measures, e.g., catalytic converters. These options are described in the next chapter.

\section{LEAST-COST ENERGY SUPPLY}

Many final energy types can be supplied in a variety of ways. This is obvious in the case of electricity and district heat, but it also applies for example to coal (which can be extracted from different domestic mines or imported). Different supply options have associated with them different costs and air emissions. Moreover, there are intertemporal links among supply decisions-to cite an obvious example, a decision to invest in new power plant capacity has consequences for the costs of meeting future electricity demands.

Once final energy demands are projected, the means for satisfying these demands are determined as the solution of a dynamic linear programming algorithm that minimizes the present value of supplying the specified energy demands, subject to specified emission constraints and constraints imposed by the capital stock. The nature of the emission constraints depends on the policy scenario being considered, as discussed in the next chapter.

The model includes as decision variables both the operation of existing plant and equipment and investment in new equipment, 
including investment in cleaner new plant or environmental retrofit. Existing plant may also be scrapped before it is fully depreciated. Because the sequences of energy supply and conversion activities are the solution of a dynanic optimization problem, they take into account the intertemporal linkages among decisions noted above.

Over 70 technologies and 22 primary energy types are included in the framework, including energy imports and exports. Among the most important energy conversion processes considered are coal and lignite fired power plants, combined heat and power plants, district heating plants, and power or heating plants operated by industrial concems. Environmental abatement options include hard coal cleaning, wet and dry process flue gas desulphurization in coal and lignite plants, flue gas denitrification, and particulate collectors (bag filters and electrostatic precipitators). Other options include new investment in low-emission energy conversion processes, such as gas combined cycle plants, coal-burning fluidized bed plants, coal gasification, and residual oil gasification.

The optimization model includes capital costs and fuel and operating costs for both primary fuel production and energy conversion processes. ${ }^{9}$ Production and conversion capacities constrain utilization of facilities in any period, based on assumed capacity availability factors. ${ }^{10}$ The model solution provides both a "merit order" for technology use in any period, subject to

\footnotetext{
To limit a bias in the model dway from capitalintensive outcomes in periods toward the end fir the decision horizon, capital cosis include only the amount of investment that is depreciable under normal conditions within the horizon. In addition, results in Chapter 5 are reported only to 2010 to avoid end period bias.

10These factors rauge from 0.74 for new coal power plants down to 0.5 or less for combined heat and power plants.
}

prevailing environmental constraints, and a sequence of capital investments over time. This sequence reflects changes in demand and environmental constraints, along with the dynamics of capacity depreciation or scrappage and exogenously specified limits on total investment resources.

Minimization of the present value cost of energy supplies is the outcome achieved by an ideal competitive market. Thus, an important assumption in our use of the costminimization model is that actual energy markets in Poland will perform effectively over the time horizon. In particular, we are assuming that prices reflect full marginal costs of energy supplies and that individual energy suppliers respond cost-effectively to these price signals. These assumptions seem reasonable, as noted in Chapters 4 and 6 , although some government regulation of the energy sector (especially electricity) and subsidization of energy producers (e.g., highcost coal mines) occurs even in advanced industrial countries. ${ }^{11}$

It should also be noted that the energy supply and conversion model, and the energy demand projections, are deterministic. A non-stochastic approach is a disadvantage for our policy analysis, in that we cannot explore differences in the performance of emission fees and permit systems ir. the presence of uncertainty about emissions and abatement costs. ${ }^{12}$ We regard this as an important subject for further research.

\footnotetext{
11 Another important concern is whether the levels of investment calculated by the model are feasible in the capital-strapped Polish economy. Investment levels implied by the model are discussed in Chapter 5 . 12With emissiou fees, the equilibrium marginal cost of abatement (equal to the tax) is predetermined but emissions are not. The opposite is true with permit trading. The outcomes with fees and permits therefore diverges in the presence of uncertainties about emissions and costs (see Weitzman 1974 for further fiscussion). The complexity of the model used bere precluded even 2 less direct assessmen of
} 


\section{MEASURING SOCIAL COSTS OF ABATEMENT}

Having introduced the simulation framework, we now retum to the issue of how the social cost of pollution abatement can be calculared using the model. To do this we refer again to Figure 2.1. The social cost in that figure is represented as Area $(A+B+C)$.

Suppose first that $S^{0}$ represents the aggregate marginal cost curve of energy supply in the Base Case, without newly instituted controls. The area under $S^{0}$ out to the Base Case consumption level $\mathrm{Q}^{0}$, Area $(E+F)$, is the Base Case value of the objective function being minimized in the optimization model described above. Now suppose that $\mathbf{S}^{\mathbf{1}}$ is the aggregate marginal cost curve for energy supply, with some set of environmental standards applied to the large stationary sources included in the optimization model. The area under the curve $S^{1}$ out to the new consumption level $Q^{1}$, Area $(A+E)$, is the new value of the objective function in the optimization. The difference between the two values of the objective function thus is Area (A) minus Area ( $F)$. If we add to this the amount $\mathrm{P}^{0}\left(\mathrm{Q}^{0}-\mathrm{Q}^{1}\right)=$ Area $(\mathrm{F}+\mathrm{C})$, the value of reduced energy use at the original price $\mathrm{PO}$. the result is Area $(A+C)$.

We have thus far shown that two of the three components needed to measure the social cost of irmposing abatement standards on large stationary sources-increases in costs of inframarginal energy supply and a drop in producer surplus from reduced energy use-can be recovered directly from the optimization model plus a simple arithmetic adjustment. The third component, the consurner surplus loss, is represented by the area of triangle $B$. We denote this cost by

uncertainty impacts through sensitivity amalysis (see Dowlatabadi and Toman 1991 for an illustration). $\triangle C S$. Using the definition of demand elasticity, this loss can be approximated by

$$
\Delta C S=0.5\left(Q^{0}-Q^{1}\right)^{2}\left(P^{0} / Q^{0}\right)\left(1 / e_{D}\right)
$$

where $e_{D}$ is the absolute value of the price elasticity of energy demand given by the curve D.

The above argument applies only to the imposition of fixed standards on large stationary sources in the optimization model. However, it is easily generalized to other policy scenarios. For example, with emission or fuel taxes the schedule $S^{1}$ is the marginal cost of energy supply, including the tax. To determine the social cost of pollution control, it is then necessary to net out government tax revenues (a transfer payment). ${ }^{13}$ In addition, some pollution control measures are imposed on final energy demands rather than on primary energy production and conversion. Important examples of such controls in this study are restrictions on household coal use and various transportation measures like catalytic converter requirements. These costs are calculated separately and added to control costs indicated by the optimization model.

\footnotetext{
13No such netting is needed with emission trading when permits are grandfathered to sources and no revenue is transferred to the government.
} 


\section{Chapter 4}

\section{DESIGN OF SCENARIOS}

We describe the basic economic assumprions underlying the model runs in the first section; the different sets of environmental standards examined in the study in the second section; and, in the third and final section of the chapter, we describe the different economic policy scenarios examined, as alternative means to meet a particular set of standards. Detailed numerical information on the scenarios can be found in Appendix 1 (Tables A1.1-A1.15).

\section{BASIC ECONOMIC ASSUMPTIONS}

Table A1.1 lists the basic economic output projections on which the energy analyses rely. Total GNP in 1995 is assumed to be five percent above the 1990 level, reflecting recovery from the ourput shock of the early 1990s. GNP then grows at abour 4.5 percent each year until 2000 , a figure consistent with projections by the World Bank and by the Polish Ministry of Industry and Trade (Bojarski et al. 1992). After 2000, a four percent annual growth rate is assumed (Cohen 1991), a relatively moderate assumption (Rollo and Stem 1992 propose 5 percent annual growth in their "optimistic" scenario).

Substantial change in the structure of the economy also is assumed. Table A1.1 shows projections of a considerable decline in industry's share of GNP, along with significant declines in constnuction, while "other" (the service sector) grows substantially. ${ }^{14}$ Table A1.2 looks in more detail at energy-intensive sectors of the

\footnotetext{
${ }^{14}$ The projections are based on national income accounting conventions derived from the previous economic regime. which placed litle emphasis on measuring services.
}

economy. It shows substantial projected declines in ferrous metallurgy and relatively static behavior in other industries, while home construction and privare vehicles expand considerably. These assumed changes reflect the judgments of various Polish experts based on official national statistics, assessments of sectoral performance, and demographic assumptions (population change, household formation).

Energy prices are the other key element needed to establish the scenarios. Projections of intemational prices for (traded) primary fuel types used in the simulations are shown in Table Al.3. These are broadly consistent with World Bank and other intemarional projections. Over 1990-2010, world crude oil prices are projected to rise by about 50 percent; coal prices by about 20 percent; and gas prices by around 40 percent.

Domestic energy prices to end-users depend on intemational prices, domestic primary production costs, conversion costs for electricity and district heat, delivery costs (particularly transmission and distribution costs for the network energy sourceselectricity, district heat, and gas), excise taxes, and on assumptions about economic pricing of energy to end-users. Prior to 1990. energy prices in Poland were far below economic costs. Over the subsequent two years, considerable progress has been made in rationalizing energy prices. Energy prices to industry by mid-1992 were at or close to economic costs. Mine-mouth coal prices were at export parity, and liquid fuel prices reflected all production and delivery costs, as well as substantial taxes in the latter case. Prices of network fuels to households in mid1992, while well above 1990 levels, still 
needed to increase another 50-100 percent to reflect economic costs.

A basic assumption underlying the study, as nored in Chapter 3 , is that full economic pricing of all final energy sources will be in place by 1995: price is assumed to reflect the full marginal cost of supply plus any excise taxes that are applied. We also assume that taxes on liquid fuels, in percentage terms, will rise to Western European norms by 1995 . These assumptions generate the projections of final energy prices shown in Table Al.4; Table A1.5 records the delivery and tax markups. The prices in Table A1.4 underlie the projection of final energy demands in the Base Case, without additional environmental initiatives that elevate prices. For the network energy sources, the prices are broadly consistent with economic costs calculated by the supply optimization part of the model described in Chapter 3.15

Environmental policies that raise delivered final energy prices relative to the Base Case also reduce demands relative to the Base Case. The own-price elasticities used to make these aemand adjustments are shown in Table Al.6 (as already noted, crossprice effects are ignored). These figures in Table A1.6 are broadly consistent with other estimates of long-run elasticities (Bohi 1981, Bates and Moore 1992). We emphasize that the elasticities shown are not used to obtain the time path of Base Case demand adjustments, given the sharp price increases since 1990.

\footnotetext{
15 Marginal cost is not easily defined in a multiontput multiperiod linear programming model in which small changes in activity levels can have nonmarginal effects on the dual variables. Nevertheless, the prices in Table Al. 4 can be shown essentially to cover the full market costs of energy supply in the absence of requirements for emission abatement.
}

\section{ALTERNATIVE EMISSION STANDARDS}

In the Base Case scenario (BASE) no new environmental policies are employed, but some policies in non-energy industries that reflect both better resource management and lower emissions are continued (e.g., in metallurgy and cement manufacturing). In the transport sector, a new generation of diesel engines, with emissions comparable to current West European standards, is introduced (though existing trucks do not face accelerated phaseout). These engines produce 20 percent less $\mathrm{NO}_{x}$ than engines currently used in Poland.

Relative to the Base Case, four different sets of standards are considered. We label these Polish "Command-and-Control" Standards, European Community Standards, German Standards, and Flat Rate Reductions.

\section{Polish "Command-and-Control" Standards (CAC)}

The CAC scenario imposes plant level performance standards for large stationary sources (expressed in pollutants per unit fuel input), consistent with limits defined in 1990 by the Ministry of Environmental Protection, Natural Resources and Forestry in is Ordinance on the Protection of Air Against Pollurion. The limits on $\mathrm{SO}_{2}, \mathrm{NO}_{x}$, and $\mathrm{PM}$ from stationary sources are shown in Tables A1.7-A1.9. The standards for "new" installations (begun after the Ordinance and put into operation after 1994) start in 1995. Existing sources must meet weaker interim standards until 2000, the second year reported in the projection analysis, after which they must meet standards that are tighter than the interim standards but weaker than the new-source standards (in the Ordinance, the actual changeover year is 1998). The nature of these standards is 
spelled out below. ${ }^{16}$ Note that these are plant level standards, so some intraplant emission trading across sources is assumed to be possible even in this case.

In addition to stationary source controls, our CAC scenario includes a number of regulations for the household and transport sectors which, while plausible, have not yet been incorporated in Polish environmental policy: a ban on urban coal use by houscholds and a requirement for caralytic converters on all cars. These restrictions are phased in to be 50 percent effective in 2000 and 100 percent effective in 2005. After 2000, an addirional 30 percent reduction in heavy diesel engine emissions also is imposed, in line with US norms, and the sulphur content of diesel oil is assumed to drop from 0.6 percent to 0.15 percent.

It is important to note that our application of the Polish large source standards is at the plant level, rather than at the level of individual sources (e.g., boilers) as the standards are originally stated, ${ }^{17}$ reflecting the fact that the model is concerned with types of plants rather than separate sources within plants. In applying the standards at the plant level we implicitly assume a capacity for trading emission reductions across sources within plants. As discussed in Chapter ó, this appears to be consistent with how the Ministry's 1990 Ordinance currently is being interpreted in Poland. Note also that with this definition of $\mathrm{CAC}$, the scenario with $\mathrm{SO}_{2}$ emissions trading defined below should be interpreted as involving rading among as weil as within plants.

\footnotetext{
${ }^{16}$ In practice there is a third category of plant, e.g., those started before the Ondinance was passed but put into service afterwards, which must meet the oldsource fuel standards as interim standards but convert to new-source standards by 1998 .

${ }^{17}$ This also applies to our scenarios with European Community and German emissions standards, defined below.
}

\section{European Community Standards (EEC)}

The EEC scenario uses target reductions in $\mathrm{SO}_{2}$ and $\mathrm{NO}_{x}$ emissions from existing sources that are embodied in the $1988 \mathrm{EC}$ Large Combustion Plant Directive (IEA 1992). These call for $\mathrm{SO}_{2}$ reductions of 25 percent by 1993, 43 percent by 1995, and 60 percent by 2003. $\mathrm{NO}_{\mathrm{x}}$ reductions from existing sources are to be 20 percent by 1993 and 36 percent by 1998 . In the model, the $\mathrm{SO}_{2}$ reductions are applied to Poland in 1995,2000 , and 2005 respectively; the $\mathrm{NO}_{x}$ reductions are applied in 1995 and 2000.

In addition to existing source controls, the EEC scenario includes controls on new stationary sources. These standards are country-specific, but typical standards are as shown in Tables A1.10-A1.12.18 They are assumed to apply starting in the first projection year, 1995. Finally, the ban on urban coal use and the catalytic converter requirement in CAC are carried over to EEC. To simplify computations, we set final demand in EEC at CAC levels, ignoring how increases in final energy price relative to CAC affect demand.

\section{German Standards (GER)}

The GER scenario is similar to EEC but with a different set of large plant constraints, as shown in Tables A1.13-A1.15. Existing plants can meet interim $\mathrm{SO}_{2}$ standards until 1993, after which they must be retrofitted to meet new plant standards or closed. In

\footnotetext{
${ }^{I 8} \mathrm{EC}$ and German standards are actually expressed in $\mathrm{mg} / \mathrm{Nm}^{3}$ of exhaust gas, which refers to cubic meters of dry gas at $0^{\circ} \mathrm{C}$ and 1 atmosphere of pressure. To make the standards comparable to Polish limits, conversion factors of $1 \mathrm{mg} / \mathrm{Nm}^{3}=0.35 \mathrm{~g} / \mathrm{GJ}$ fuel input for coal plants, $1 \mathrm{mg} / \mathrm{Nm}^{3}=0.30 \mathrm{~g} / \mathrm{GJ}$ fuel input for oil plants, and $1 \mathrm{mg} / \mathrm{Nm}^{3}=0.31 \mathrm{~g} / \mathrm{GJ}$ fiel input for gas plants were assumed. These are approximate conversions that ignore many differences in fuel quality and technology.
} 
adapting the $\mathrm{SO}_{2}$ standards to Polish application we apply interim standards to existing plant in 1995 and tougher standards in 2000 and subsequent projection years. New piants have to meet tougher standards starting in 1995. The GER NO $\mathrm{N}$ and particulate standards also must be met by 1995. As in EEC, final energy demands are left at the CAC level.

\section{Flat Rate Reductions (FRRED)}

The Polish CAC and the other two sets of standards impose differential constraints on large sources; for example, new sources must meet more stringent $\mathrm{SO}_{2}$ standards than existing sources. With FRRED, we aim for the same iotal emissions as in CAC (and leave final energy demands unchanged), but we allocare allowable emissions over time for each large source type in proportion to its contribution to unabated emissions in BASE. ${ }^{19}$ The comparison of CAC and FRRED thus can reveal the cost consequences of differential treatment of large sources.

\section{Comparison of Plant-Level Emission Standards}

With respect to $\mathrm{SO}_{2}, \mathrm{EC}$ and (especially) Geman plant-level standards are much stricter than Polish standards for large new facilities. Much the same is true for existing plant. In contrast, for small new facilities (e.g., mechanical grate and other boilers with capacities less than $\left.100 \mathrm{MW}_{\text {th }}\right)$, Polish standards tend to be tougher (compare, e.g., the Polish limit of $22 \mathrm{~g} / \mathrm{GJ}$ for new mechanical grate boilers to the German standard of $700 \mathrm{~g} / \mathrm{GJ}$ for small boilers).

\footnotetext{
19This is the case for both existing emitters at the start of the simulation and new emitters added during the simulation.
}

Polish $\mathrm{NO}_{\mathrm{X}}$ standards are stricter than EC and even German standards, particularly for grate firing coal plants and small gas fired plants. For PM, in contrast, Polish standards are much more liberal; generally, PM control is much less of a problem in Westem European countries. These characteristics of the control scenarios should be kept in mind since PM often is the cheapest pollutant to abate. As already noted, the main difference between CAC and FRRED is that the latter does not discriminate among sources based on size or vintage.

These differences in plant-level standards influence the total emissions projected in the different control scenarios just described. ${ }^{20}$ However, they are by no means the only factor. Nor are they a reliable guide even to the comparison of total emissions from new and old sources. Other influences include the distribution of plant by fuel type and age, and the relative cost of different control strategies. These comparisons are discussed in Chapter 5.

\section{ALTERNATIVE ECONOMIC INSTRUMENTS}

The second set of scenarios we consider involves the application of different types of economic policy instruments. With one exception, these scenarios seek to achieve the same total emissions as those projected in CAC (based in part on 1990 Polish legal standards).

\section{Uniform Emissions Taxes on Lange Stationary Sources (ETAXI)}

ETAXl is based on the same final energy demands as CAC, including the ban on urban coal use and the restrictions on transport emissions (e.g., caralytic converter

\footnotetext{
${ }^{20}$ They also allow us to account for bow new source bias may affect the pattern of plant investment.
} 
requirements). From this starting point, emissions taxes on large-source emissions of $\mathrm{SO}_{2}, \mathrm{NO}_{\mathrm{X}}$, and $\mathrm{PM}$ are found that yield the same national emissions as CAC. Because final demands are the same as $\mathrm{CAC}$, this case indicates the effect on total abatement costs of more flexible large-source emission controls compared to fixed plant-level standards. ${ }^{21}$

\section{$\mathrm{SO}_{2}$ Trading by Large Sources (SO2TR)}

SO2TR uses the same starting point as ETAXI (CAC final energy demands, ban on urban coal use, transport controls). It also imposes the CAC plant-level standards for $\mathrm{NO}_{\mathrm{X}}$ and $\mathrm{PM}$. For large-source $\mathrm{SO}_{2}$ control (all the sources in the optimization model), a national market for $\mathrm{SO}_{2}$ permits is simulated by solving the optimization model with a limit only on aggregate $\mathrm{SO}_{2}$ emissions (versus plant-level standards that allow only trading among sources within plants). Allowances are not bankable (so we are not simulating an intertemporally first-best $\mathrm{SO}_{2}$ trading system that would allow more irregular emissions over time). 22

To calculate compliance costs for traders, initial permit allocations are grandfathered to existing emitters in 1990 based on 1990 emissions shares. Existing

\footnotetext{
${ }^{21}$ Note that because the model does not distinguish the location of pollution sources, this scenario generates uniform national emission tax rates for large-source emissions of $\mathrm{NO}_{\mathbf{x}}$ and PM as well as $\mathrm{SO}_{2}$. Such uniform taxes are not socially optimal from the standpoint of pollution control since the pollutants in question do not mix uniformly at a national level and different regional control severities generally are appropriate to rellect variations in ambient conditions. ETAX1 should be interpreted only in relation to CAC, not as an endorsement of uniform emission tax rates.

${ }^{22}$ SO2TR also does not allow for trading between energy converters and final demanders (e.g., a local power plant paying to reduce emissions from household coal use by subsidizing fuel substitution).
}

emitters face a declining sequence of endowments over time, consistent with the time path of emissions in CAC (see Chapter 5). New emitters must acquire permits to cover all their emissions, starting from their initial years of operation. ${ }^{23}$

\section{Coal Tax (COALTX)}

COALTX, a 100 percent tax on coal, the most polluting fuel, is imposed (coke, a smokeless fuel, is exempted). No regulatory restrictions on emissions (in energy conversion, households, or transport) are imposed, and no attempt is made to achieve emissions parity with CAC. Total final demands also differ from $C A C$; they are calculated by altering BASE demands to reflect the effects of the tax on prices of coal, electricity, and heat.

\section{Uniform Emission Taxes on All Sources (ETAX2)}

ETAX2 relaxes all fixed standards and controls, including those on households and transport, while imposing $\mathrm{SO}_{2}, \mathrm{NO}_{x}$, and $\mathrm{PM}$ emission taxes on all sources to yield the same total emissions as CAC. Large energyconversion sources respond to taxes in the optimization model as in ETAX1. Household transport and other end-use emissions are curbed by higher fuel taxes, set to be equivalent to the large-source emission taxes, based on the average emissions per unit of fuel use. ${ }^{24}$ Compared to EIAX1, this

\footnotetext{
${ }^{23}$ The cotal emission erdowment is not quite the same as total CAC emissions because certain small sources - such as municipal heating plants and some sources of process emissions-are omitted from trading. ${ }^{24}$ This scenario requires a two-level set of iterations. For any set of final demands. emission laxes are varied within the energy conversion optimization model until total emissions are (approximately) equal to CAC levels. The "outer feedback loop" involves successive revisions of final demand, starting at
} 
scenario allows for a different distribution of emission control between the large stationary sources and other emitters since the latter also are subject to incentive-based instruments. Options for end-use fuel and technology switching (e.g., voluntary shifts to catalytic converters or gas use in households) that might be induced by high fuel taxes are ignored. Such substitution possibilities lie beyond the scope of the model. At least in the transport sector, there is reason to suspect that such switching would not be costeffective for the tax levels we impose (see Chapter 5).

\section{SUMMARY}

Tables 4.1 and 4.2 summarize important characteristics of all the standards and economic policy scenarios we consider. As already noted, the structure of the model forces on us some compromises in defining policy scenarios that correspond to actual policy design issues. Nevertheless, we believe that the scenarios are capable of illustrating both the incremental costs of different standards and the cost consequences of different economic policy mechanisms. The comparisons are made in the next chapter.
BASE levels, to reflect the effects of the emissions taxes. As a consistency check the optimization model was run with only aggregate emission constraints (as if there were a single market for all sources to irade emissions). This outcome should be the theoretical dual to uniform emission taxes on all sources set to yield the same total emissions. In practice the result in the consistency check was essentially the same as in ETAX2, taking into account the inevitable rounding problems. 
Table 4.1. Characteristics of Alternative Standards Scenarios

\begin{tabular}{|c|c|c|c|c|}
\hline & $\mathrm{CAC}$ & FRRED & EEC & GER \\
\hline $\begin{array}{l}\text { Baseline final energy } \\
\text { demand }\end{array}$ & BASE & $\mathrm{CAC}$ & CAC & CAC \\
\hline $\begin{array}{l}\text { Demand adjustment for } \\
\text { incremental energy } \\
\text { price increase relative } \\
\text { to baseline }\end{array}$ & Yes & $\begin{array}{l}\text { Yes } \\
\text { (reflecting } \\
\text { different } \\
\text { distribution } \\
\text { of control } \\
\text { effort) }\end{array}$ & No & No \\
\hline $\begin{array}{l}\text { Nature of stationary } \\
\text { source emission } \\
\text { standards }\end{array}$ & $\begin{array}{l}\text { Plant level } \\
\text { (Tables } \\
\text { A1.7-A1.9) }\end{array}$ & $\begin{array}{l}\text { Plant level } \\
\text { (Pro rata } \\
\text { reductions } \\
\text { relative to } \\
\text { BASE; } \\
\text { total } \\
\text { emissions } \\
\text { same as } \\
\text { CAC) }\end{array}$ & $\begin{array}{l}\text { Plant level } \\
\text { (Tables } \\
\text { A1.10-A1.12) }\end{array}$ & $\begin{array}{l}\text { Plant level } \\
\text { (Tables } \\
\text { A1.13-A1.15) }\end{array}$ \\
\hline $\begin{array}{l}\text { Household and } \\
\text { transport sector } \\
\text { controls }\end{array}$ & Yes & Yes & Yes & Yes \\
\hline
\end{tabular}


Table 4.2. Characteristics of CAC and Alternative Economic Instrument Scenarios

\begin{tabular}{|c|c|c|c|c|c|}
\hline & CAC & ETAXI & SO2TR & ETAX2 & COALTX \\
\hline $\begin{array}{l}\text { Baseline } \\
\text { final energy } \\
\text { demand }\end{array}$ & BASE & $\mathrm{CAC}$ & $\mathrm{CAC}$ & BASE & BASE \\
\hline $\begin{array}{l}\text { Demand } \\
\text { adjustment } \\
\text { for } \\
\text { incremental } \\
\text { energy price } \\
\text { increase } \\
\text { relative to } \\
\text { baseline }\end{array}$ & Yes & No & No & Yes & Yes \\
\hline $\begin{array}{l}\text { Narure of } \\
\text { stationary } \\
\text { source } \\
\text { emission } \\
\text { standards }\end{array}$ & $\begin{array}{l}\text { Plant level } \\
\text { (Tables } \\
\text { A1.7-A1.9) }\end{array}$ & $\begin{array}{c}\text { None; } \\
\text { national } \\
\text { emissions } \\
\text { targets = } \\
\text { CAC } \\
\text { emissions }\end{array}$ & $\begin{array}{c}\text { CAC plant } \\
\text { stds for } \mathrm{NO}_{\mathrm{X}} \text { ' } \\
\mathrm{PM} \text {; national } \\
\mathrm{SO}_{2} \\
\text { emissions } \\
\text { target }=\mathrm{CAC} \\
\text { emissions }\end{array}$ & $\begin{array}{c}\text { None; } \\
\text { national } \\
\text { emissions } \\
\text { targets = } \\
\text { CAC } \\
\text { emissions }\end{array}$ & $\begin{array}{l}\text { None (coal } \\
\text { demand } \\
\text { taxed) }\end{array}$ \\
\hline $\begin{array}{l}\text { Humisehold } \\
\text { and } \\
\text { transport } \\
\text { sector } \\
\text { controls }\end{array}$ & Yes & Yes & Yes & $\begin{array}{l}\text { No (fuels are } \\
\text { taxed based } \\
\text { on average } \\
\text { emissions per } \\
\text { unit) }\end{array}$ & $\begin{array}{l}\text { No (coal } \\
\text { use taxed) }\end{array}$ \\
\hline
\end{tabular}




\section{Chapter 5}

\section{MODEL RESULTS}

We present in this chapter a summary of the most significant results derived from the simulations. Details can be found in Appendix 2 (Tables A2.1-A2.14).

\section{BASE CASE SCENARIO}

Table A2.1 summarizes information about the time paths of energy demand in the Base Case. GNP in 2000 is somewhat above the 1988 level, but both primary and final energy demands remain considerably below 1988 values; energy intensity contracts by 20 percent over 1988-2000. Even in 2010, when GNP is well above the 1988 level, the continued drop in energy intensity of GNP leads to a much lower growth in total energy demands (energy intensity in 2010 is 40 percent less than in 1988). ${ }^{25}$ Table A2.2 amplifies this point by showing relative changes in sectoral energy intensities. Although energy intensity in the residential sector returns to the 1988 level in 2000 , and rises slightly thereafter, heated dwelling space is projected to increase over 40 percent relative to 1988 , so that residential energy per $\mathrm{m}^{3}$ of living area actually declines. In all other sectors, energy use per unit of value added declines, even after recovery from the output contraction of the early 1990s.

Significant changes also are observed in the structure of energy demands. As shown in Table A2.L, the share of final demand for solid fuels drops sharply, while gas, liquid fuels, and electricity increase their shares. ${ }^{26}$

\footnotetext{
${ }^{25}$ Over $1988-2010$, the elasticity of final energy demand with respect to GNP is only 0.12 , much lower than comparable experience in Western economies. ${ }^{26}$ Note that the relative electricity intensity of GNP remains well above overall energy intensity (and even increases during the early 1990s). Nevertheless, the
}

Corresponding declines in coal and lignite shares, and increases in oil and gas, are obierved in primary demand.

Table A2.3 lists Base Case emissions by type and sector. Except for $\mathrm{CO}_{2}$, all of the aggregate emissions are lower in 2010 than in 1988. The declines by 2010 are 7 percent for $\mathrm{SO}_{2}, 3$ percent for $\mathrm{NO}_{\chi}$, and 44 percent for PM compared to 1988. PM emissions decline monotonically, while $\mathrm{SO}_{2}$ and $\mathrm{NO}_{\mathrm{x}}$ increase after 2000 but still do not return to 1988 levels. Conceming trends in the distribution of emissions by sector, PM drops fairly consistently across sectors, whereas the fall in $\mathrm{NO}_{\mathrm{K}}$ and $\mathrm{SO}_{2}$ occurs in final use and in industrial boilers. Some technological factors help to explain the pattems in Table A2.3: improved diesel engines, with 20 percent decreases in $\mathrm{NO}_{\boldsymbol{\lambda}}$ emissions, enter the scenario, and particulate emissions drop from better control in some industrial processes and a limited shift toward coal beneficiation (even without new environmental controls).

\section{ENERGY AND EMISSIONS DIFFERENCES ACROSS STANDARDS SCENARIOS}

We consider here the impacts of different environmental standards (CAC. EEC, GER, and FRRED). Final energy demand in CAC (and thus in the other scenarios just listed) is lower than in BASE, as a consequence of higher prices from environmental controls. but the difference is minor-only 2-3 percent. ${ }^{27}$ Thus, we focus here on primary

\footnotetext{
elasticity of electricity demand with respect to GNP over $1988-2010$ is still only 0.8 . well below past patterns in Western economies.

${ }^{27}$ Recall from Table 4.1 that by assumption. final demands in EEC and GER are the same as in CAC.
} 
energy demands, where the differences are still modest but slightly more pronounced.

Table A2.4 summarizes the results for primary energy demands. Coal demand in CAC is about four percent lower than in BASE in 2010, while gas demand is about eight percent higher. As expected, environmental standards make a switch toward lower-emitting fuel more attractive, a phenomenon that is even more pronounced in FRRED. While total primary energy demand and its sectoral pattem under EEC are very similar to $\mathrm{CAC}$, there is greater switching to lower-emitting sources with the stricter German standards. It is interesting to note that the German standards require more primary energy than the simple pro rata emission reductions in FRRED, to achieve the same final energy demands, reflecting the need for greater primary energy application to achieve the tighter GER standards (e.g., through flue gas desulphurization).

Table A2.5 shows the trajectories of emissions by source and type with the various standards. We noted in the previous subsection that, with the exception of $\mathrm{CO}_{2}$. emissions in BASE (without new environmental initiatives) fall off considerably relative to 1988 levels. In CAC, the new Polish legal standards produce a further substantial drop in emissions, again with the exception of $\mathrm{CO}_{2}$. In $2000, \mathrm{SO}_{2}$ and $\mathrm{NO}_{x}$ emissions decline by roughly a quarter relative to BASE, while PM declines by about a half. In EEC, the $\mathrm{SO}_{2}$ and $\mathrm{NO}_{\mathrm{x}}$ reductions are similar to those in CAC out to 2000, while PM emissions are about 20 percent lower; however, by $2010, \mathrm{SO}_{2}$ emissions are 12 percent lower than CAC while $\mathrm{NO}_{\mathrm{x}}$ is about 2 percent higher. The GER controls on $\mathrm{SO}_{2}, \mathrm{NO}_{\mathrm{x}}$, and $\mathrm{PM}$ are truly stringent, yielding emissions in 2000 and 2010 that are

There are final demand differences between CAC and FRRED, but they are minor.
40-50 percent, $30-35$ percent and 30 percent below CAC respectively.

It is also interesting to note differences across scenarios in the sources of emission reductions in Table A2.5. For $\mathrm{SO}_{2}$ reductions, all the control scenarios except FRRED put a greater burden relative to BASE on new sources than existing sources: whereas new power and combined heat and power plants in BASE and FRRED are responsible for 10 percent of $\mathrm{SO}_{2}$ emissions in 2000 and 28 percent of emissions in 2010. they generate only 2 percent of $\mathrm{SO}_{2}$ emissions in 2000 and 6-8 percent of emissions in 2010 under CAC, EEC, and GER.

\section{ENERGY AND EMISSIONS DIFFERENCES ACROSS ECONOMIC POLICY SCENARIOS}

We next consider variations between CAC and scenarios involving economic policy instruments. Table A2.6 indicates that the effects of economic incentives on primary energy demands are minor, in the case of ETAX1 and SO2TR. With regard to emissions, the main interest lies in the distribution of emissions across sources, since the aggregates are (essentially) identical by construction. ${ }^{28}$ A more striking feature of ETAX1 and SO2TR, as shown in Table A2.7, is the alleviation of new source bias for $\mathrm{SO}_{2}$ in ETAX1 and SO2TR-new sources in these scenarios have significantly higher $\mathrm{SO}_{2}$ emissions than in CAC. The other major difference across the scenarios is that with the greater $\mathrm{SO}_{2}$ control flexibility in SO2TR and ETAX1, more $\mathrm{SO}_{2}$ abatement is undertaken by power plants and less by combined heat and power plants relative to CAC. The differences in $\mathrm{NO}_{\mathbf{x}}$ and $\mathrm{PM}$ abatement

\footnotetext{
${ }^{28}$ In some cases the iterative solution process over multiple periods does not generate exact agreement in results that in theory should be identical.
} 
between ETAX1 and CAC are minor, suggesting that any cost advantages from incentive-based control by large stationary sources derive primarily from flexibility in $\mathrm{SO}_{2}$ control.

Tables A.2.8 and A2.9 show the energy and environmental patterns for ETAX2, in which large stationary sources face emissions taxes, and other sources (household and transport) face (roughly) equivalent fuel taxes, reflecting the average emissions per unit of fuel use. Higher energy prices reduce final demand by about three percent relative to $\mathrm{CAC}$ (five percent relative to $\mathrm{BASE}$ ). The drop in primary coal demand is especially pronounced.

Pattems of emissions differ in several significant ways between ETAX2 and ETAX1. Recall that, in the latter case, only large stationary source emissions are taxed, while final demand sources (households and transport) face direct controls. In ETAX2, $\mathrm{SO}_{2}$ and $\mathrm{NO}_{\mathrm{x}}$ emissions from final users are higher than in ETAXI or CAC; the fuel taxes have less effect on these emissions sources than direct controls. As a consequence, emissions from energy conversion sources must be lower to meet the overall targets. Like ETAX1, ETAX2 has less bias against new $\mathrm{SO}_{2}$ sources than in CAC. For $\mathrm{NO}_{\mathrm{x}}$, on the other hand, it is cheaper in ETAX2 to accommodate higher end-use emissions by sharply restricting emissions from new power and from combined heat and power plants than to restrict emissions from existing stationary sources further.

The COALTX scenario is summarized in Tables A2.10 and A2.11. Predictably, the swingeing (100 percent) tax on coal significantly reduces its use relative to BASE and CAC: the final demand for solid fuels drops 21-29 percent and primary demand for hard coal drops by 17-24 percent. ${ }^{29}$

\footnotetext{
${ }^{29}$ Table A1.4 indicates that Base Case hard coal prices are \$55-60/ton for industry and \$93-98/ton for
}

However, emissions of $\mathrm{SO}_{2}, \mathrm{NO}_{\mathrm{x}}$, and $\mathrm{PM}$ are much higher relying just on the coal tax than with more bioad-based environmental policies.

\section{ECONOMIC IMPACTS OF EMISSION CONTROLS}

Tables 5.1 and 5.2 compare the social costs of abatement across the CAC and economic instrument scenarios respectively, relative to BASE. As described in Chapters 2 and 3, these costs can be separated into several categories: increased costs of energy conversion and emission reduction; loss of producer surplus; costs imposed on final energy demands in the household and transport sectors; and losses of consumer surplus from reduced final energy demands. All the costs in Tables 5.1 and 5.2 are present values over 1990-2015, calculated at a real discount rate of 12 percent. ${ }^{30}$

Table 5.1 shows that, compared to BASE, the additional cost of emission control in GER is about 70 percent higher than under any of the other sets of standards (CAC, FRRED, or EEC), reflecting the sharp cuts in $\mathrm{SO}_{2}$ and $\mathrm{NO}_{\mathrm{x}}$ emissions from stationary sources under GER. Given the interest in Poland in harmonizing with European Community standards, it is interesting that the

\footnotetext{
households in 2000 and 2010. The excise tax assumed bere doubles those prices.

${ }^{30}$ This discount rare is used to reflect the cospect of real capital scarcity and nontrivial financial risles over the next several years. A lower discount ' $'$ 'e would cause a relative increase in the present value of costs for scenarios that involve high capital investmeots in later years of the decision horizon, such as GER and ETAX2.
} 
Table 5.1. Socinl Cost of Pollution Control, 1991-2015 (CAC)

(USS billions) $)^{a /}$

SCENARIO

\begin{tabular}{|l|c|c|c|c|}
\hline Cost component & CAC & FRRED & EEC & GER \\
\hline $\begin{array}{l}\text { Large point source control } \\
\text { costs and loss of producer } \\
\text { surplus }\end{array}$ & 6.57 & 6.73 & 6.56 & 15.43 \\
\hline Lost of consumer surplus & 0.02 & 0.02 & 0.02 & 0.02 \\
\hline $\begin{array}{l}\text { Switch to gas by urban } \\
\text { households }\end{array}$ & 0.08 & 0.08 & 0.08 & 0.08 \\
\hline Transport controls & 5.89 & 5.89 & 5.89 & 5.89 \\
\hline Tolal & 12.56 & 12.72 & 12.55 & 21.42 \\
\hline
\end{tabular}

$3 /$ Discounted to 1990, 12\% real discount rate. Pollutants controlled are $\mathrm{PM}, \mathrm{SO}_{2}$, and $\mathrm{NO}_{x}$; see Chapter 4 for definitions of scenarios.

Table 5.2. Social Cost of Pollution Control, 1991-2015 (Economic Instruments) (US\$ billions)

SCENARIO

\begin{tabular}{|l|c|c|c|c|}
\hline Cost component & ETAX1 & SO2TR & ETAX2 & COALTX \\
\hline $\begin{array}{l}\text { Large point source control } \\
\text { costs and loss of producer } \\
\text { surplus }\end{array}$ & 5.30 & 5.87 & 5.51 & 9.76 \\
\hline Loss of consuner surplus & 0.02 & 0.02 & 0.22 & 1.04 \\
\hline $\begin{array}{l}\text { Switch to gas in urban } \\
\text { households }\end{array}$ & 0.08 & 0.08 & $\cdot$ &. \\
\hline $\begin{array}{l}\text { Transpon controls } \\
\text { Total }\end{array}$ & 5.89 & 5.89 & &. \\
\hline
\end{tabular}

a/Discounted to $1990.12 \%$ real discount rate. Pollutants controlled are $\mathrm{PM}_{1} \mathrm{SO}_{2}$, and $\mathrm{NO}_{\mathrm{x}}$; see Chapter 4 for definitions of scenarios. 
cost of meeting CAC is roughly the same as EEC."

Table 5.2 shows the costs of emission control with taxes and (interplant) emissions trading relative to BASE. ${ }^{32}$ These figures can he compared to the performance of CAC (which allows for intraplant trading) in Table 5.1. For policies applied to large sources (ETAXI and SO27R), the cost savings over CAC are fairly modest, partiy because fairly expensive controls in the transport sector account for almost one-half of total emission control costs (relative to BASE) in all these cases. When these controls are dropped and economic incentives are applied to all pollutants, as in ETAX2, control costs are more than halved relative to $\mathrm{CAC} .{ }^{33}$

This comparison understates the potential contribution of an incentive-based approach since, as noted previously, our version of CAC already assumes significant flexibility for polluters in restricting emissions from separate sources. Another important source of understatement is that the model ignores dynamic efficiency benefits from

\footnotetext{
${ }^{31}$ We emphasize, however, that the environmental consequences of the two sets of standards are not likely to be the same. In particular, West European standards on $\mathrm{SO}_{2}$ from large plants are tougher than Polish standards, while the reverse is true for small plants. On the other hand, the EEC standards for PM are much tighter than in CAC.

32The total cost of the COALTX scenario also is reported in Table 5.13. The main point here is thit there are considerable costs incurred for quite modest emission reductions relative to BASE: the coal tax by itself is a very cost-ineffective policy.

${ }^{33}$ As noted in Chapter 4, we do not consider the possibility that residential and transport users woxid voluntarily switch to lower-emission technologies as a consequence of the fuel taxes they face in ETAX2. Such conversion will be efficient if the present value of surplus losses from the higher taxes exceeds the opportunity cost of the new technology investment (including the cost of prematurely abandoning existing equipment). Thus our social cost figure for ETAX2. which includes these surplus losses, may overstate the cost of this scenario.
}

incentive-based policies. In pirticular, the model treats all potential tecinmologies and other strategies for emissions control as heing known in advance. In practice, incentivebased policies will provide additional motives for developing new techmologies and strategies, as noted in Chapter 2.

Table A2.12 expands on the differences between stationary and transpurt controls by comparing the unit control cost of differ.... emission reduction strategies used in the transport sector under CAC, relative in other options. While low- $\mathrm{NO}_{\mathrm{X}}$ diesel engines appear to be cost-effective methods for emission reduction, catalytic converers and diesel oil desulphurization are very expensive. ${ }^{34}$ It does not follow, however, that these transport controls should be avoided. The unit costs of emission controls alone are not a sufficient basis for judgment. since the contribution of different sources to ambient air quality and the relative harmfulness of different pollutants also affect the social interest. Mobile sources contribute only a small percentage of total emissions. but they could be disproportionately important in urban centers. Moreover, their importance may grow over time (see Chapter 1). These issues are beyond the scope of the present study to address.

According to the model, investment outlays for the energy supply and conversion system over 1991-2010 are substantial, even without new environmental controls. In BASE, total urdiscounted outlays are US $\$ 65.7$ billion over the period. with about 40 percent of these outlays (US $\$ 27.1$ billion) occurring over 1991-2000. the perind of significant economic restructuring. The

\footnotetext{
${ }^{34}$ The total cost figures in Table 5.2 indicate an even greater spread in cost-effectiveness: comparing ETAX1 and ETAX2, we find that the large cost of mandated controls can be avoided with only a modest increase in stationary source controls along with a modest decrease in consumer surplus.
} 
increases in total investment outlays under some of the environmental policies we consider are shown in Table A2.13. As might be expected, the stringency of environmental standards in GER causes a substantial jump in energy supply system investments (41 percent over BASE from 1991-2000 and 26 percent over 1991-2010). The inireases in CAC and ETAX2 are smaller, on the order of 7.9 percent (only 2 percent cver 1991-2000 for ETAX2).

Differences in standards, control methods, and taxes across the scenarios also generate variations in energy prices. To illustrate, Table 5.3 shows the increases in final energy prices relative to BASE for CAC, ETAX2, and COALTX. The effects of fixed emissions standards on final prices is relatively modest (increases range from one to seven percent). The price increases in ETAX2 are more substantial, particularly for coal, reflecting the impacts of the emissions charges. The COALTX scenario generates substantial increases in electricity and heat prices, as well as coal, though these increases are eroded over time by substitution away from coal-fueled technologies.

Table 5.4 summarizes the emissions fees in ETAX1 and ETAX2 and compares them to Polish charges as of April 1, 1993. These charges have risen sharply since 1990 , but the levels remain well below those required even to attain interim (1995) standards and are an order of magnitude too small for achieving emissions targets in 2010. Note particularly the need for large increases in PM charges. Ultimately $\mathrm{PM}$ and $\mathrm{SO}_{2}$ fees are the same order of magnitude in ETAX1 and ETAX2, whereas the current PM charge in Poland is only half the size of the current $\mathrm{SO}_{2}$ charge. As a matter of interest, the $\mathrm{NO}_{\mathrm{X}}$ tax of about US $\$ 1,000 /$ tonne in 2000 under ETAX2 translates into charges of about US\$0.06/liter on diesel fuel and US\$0.03/liter on gasoline.
The dramatic increases in taxes which are implied by ETAX1 and ETAX2, and the resulting increases in final energy prices, would spark social controversy. Unfortunately, the lack of focus in the model on individual sources makes a detailed assessment of financial burden impossible. However, some outputs of the model do help to shed light on the issue.

One concrete indicator is that the tax increases in ETAX1 and ETAX2 are calculated by the model to generate additional revenues with a present value of about US $\$ 9$ billion by 2015 . This makes the total cost of compliance (including increased fees) in ETAX 1 about 55 percent higher than in $C A C$, even though the social cost of abatement in ETAX1 is lower (see Table 5.2). The compliance cost in ETAX2 is only about 9 percent higher than in CAC. reflecting the high degree of costeffectiveness achieved with comprehensive changes. In contrast, the distribution of trading profits from large-source $\mathrm{SO}_{2}$ emission trading, with grandfathering, is shown in Table 5.5. While new sources face nontrivial costs of permit acquisition and some existing sources (especially existing lignite plants) make substantial trading profits, there is no net transfer of funds away from polluters and the total compliance costs appear to be much lower than under the tax approaches. ${ }^{35}$

The changed energy prices in all scenarios have important distributional effects on households, but they are overwhelmingly due to energy price reforms rather than environmental policies. In BASE, the share of household expenditure allocated to fuel and power increases between 1992 and 2000

\footnotetext{
${ }^{35} \mathrm{Keep}$ in mind that ETAX1 and ETAX2 involve charges on $\mathrm{NO}_{\mathrm{X}}$ and $\mathrm{PM}$ as well as $\mathrm{SO}_{2}$. whereas Table 5.5 describes expenses only for $\mathrm{SO}_{2}$ permits.
} 
Table 5.3. Energy Price Indices to Final Consumers for Scenarios (Base $=1.0)$

\begin{tabular}{|c|c|c|c|c|c|c|}
\hline \multirow{2}{*}{ Fuel/Scenario } & \multicolumn{2}{|c|}{1995} & \multicolumn{2}{|c|}{2000} & \multicolumn{2}{|c|}{2010} \\
\hline & Industry & Housing & Industry & Housing & Industry & Housing \\
\hline $\begin{array}{l}\text { Hard coal } \\
\text { ETAX2 } \\
\text { COALTX }\end{array}$ & $\begin{array}{l}1.17 \\
2.00\end{array}$ & $\begin{array}{l}1.13 \\
2.00 \\
\end{array}$ & $\begin{array}{l}1.29 \\
2.00 \\
\end{array}$ & $\begin{array}{l}1.23 \\
2.00 \\
\end{array}$ & $\begin{array}{l}1.35 \\
2.00 \\
\end{array}$ & $\begin{array}{l}1.28 \\
2.00 \\
\end{array}$ \\
\hline $\begin{array}{l}\text { Gasoline } \\
\text { CAC } \\
\text { ETAX2 } \\
\end{array}$ & $\begin{array}{l}1.01 \\
1.02 \\
\end{array}$ & $\begin{array}{l}1.01 \\
1.02 \\
\end{array}$ & $\begin{array}{r}1.01 \\
1.03 \\
\end{array}$ & $\begin{array}{l}1.01 \\
1.03 \\
\end{array}$ & $\begin{array}{l}1.03 \\
1.06 \\
\end{array}$ & $\begin{array}{l}1.03 \\
1.06 \\
\end{array}$ \\
\hline $\begin{array}{l}\text { Diesel oil } \\
\text { CAC } \\
\text { ETAX2 }\end{array}$ & $\begin{array}{l}1.01 \\
1.07\end{array}$ & $\begin{array}{l}1.01 \\
1.07\end{array}$ & $\begin{array}{l}1.02 \\
1.10\end{array}$ & $\begin{array}{l}1.02 \\
1.10\end{array}$ & $\begin{array}{l}1.04 \\
1.20\end{array}$ & $\begin{array}{l}1.04 \\
1.20\end{array}$ \\
\hline $\begin{array}{l}\text { Fuel oil (heavy) } \\
\text { CAC } \\
\text { ETAX2 }\end{array}$ & $\begin{array}{l}1.00 \\
1.07 \\
\end{array}$ & . & $\begin{array}{l}1.02 \\
1.34 \\
\end{array}$ & . & $\begin{array}{l}1.04 \\
1.35 \\
\end{array}$ & . \\
\hline $\begin{array}{l}\text { Electricity } \\
\text { CAC } \\
\text { ETAX2 } \\
\text { COALTX } \\
\end{array}$ & $\begin{array}{l}1.02 \\
1.10 \\
1.20 \\
\end{array}$ & $\begin{array}{l}1.01 \\
1.07 \\
1.14 \\
\end{array}$ & $\begin{array}{l}1.05 \\
1.09 \\
1.10 \\
\end{array}$ & $\begin{array}{l}1.03 \\
1.06 \\
1.06 \\
\end{array}$ & $\begin{array}{l}1.07 \\
1.10 \\
1.10\end{array}$ & $\begin{array}{l}1.04 \\
1.06 \\
1.06\end{array}$ \\
\hline $\begin{array}{l}\text { District heat } \\
\text { CAC } \\
\text { ETAX2 } \\
\text { COALTX }\end{array}$ & $\begin{array}{l}1.03 \\
1.09 \\
1.23 \\
\end{array}$ & $\begin{array}{l}1.02 \\
1.06 \\
1.09 \\
\end{array}$ & $\begin{array}{l}1.03 \\
1.08 \\
1.14 \\
\end{array}$ & $\begin{array}{l}1.02 \\
1.05 \\
1.05\end{array}$ & $\begin{array}{l}1.04 \\
1.08 \\
1.12 \\
\end{array}$ & $\begin{array}{l}1.02 \\
1.02 \\
1.03 \\
\end{array}$ \\
\hline
\end{tabular}


lable 5.4. Pollution Fees (Actual) and Taxes for ETAX1 and ETAX2 (US\$/tonne)

\begin{tabular}{||c|c|c|c|c|c|c|c|c||}
\hline \multirow{2}{*}{ Pollutant } & \multirow{2}{*}{$\begin{array}{c}1990 \\
\text { (end of yr) }\end{array}$} & \multirow{2}{*}{$\begin{array}{c}1993 \\
\text { (April) }\end{array}$} & \multicolumn{2}{|c|}{1995} & \multicolumn{2}{|c|}{2000} & \multicolumn{2}{c|}{2010} \\
\cline { 4 - 9 } & & & ETAX1 & ETAX2 & ETAX1 & ETAX2 & ETAX1 & ETAX2 \\
\hline $\mathrm{SO}_{2}$ & 28 & 75 & 476 & 430 & 536 & 541 & 789 & 780 \\
\hline $\mathrm{NO}_{x}$ & 28 & 75 & 1029 & 542 & 1029 & 1029 & 1029 & 2716 \\
\hline $\mathrm{PM}$ & 7 & 38 & 177 & 176 & 640 & 640 & 640 & 640 \\
\hline
\end{tabular}

Table 5.5. Costs and Profits from Sulphur Dioxide Trading

\begin{tabular}{|c|c|c|c|c|}
\hline \multirow{3}{*}{$\begin{array}{l}\text { Trading } \\
\text { category }\end{array}$} & \multicolumn{3}{|c|}{$\mathrm{SO}_{2}$ emissions (thousand tonnes) } & \multirow{3}{*}{$\begin{array}{l}\text { Trading gains } \\
\text { or losses }\end{array}$} \\
\hline & \multirow{2}{*}{1990} & \multicolumn{2}{|c|}{2000} & \\
\hline & & $\begin{array}{c}\text { Initial } \\
\text { endowment }\end{array}$ & SO2TR & \\
\hline $\begin{array}{l}\text { Public power plants: } \\
\text { - new (hard coal) } \\
\text { - existing (hard coal) } \\
\text { - existing (lignite) } \\
\text { Public CHP plants: } \\
\text { - new } \\
\text { - existing } \\
\text { Industrial power plants: } \\
\text { - new } \\
\text { - existing } \\
\text { Industrial heating plants: } \\
\text { - existing } \\
\text { Municipal heating plants: } \\
\text { - existing }\end{array}$ & $\begin{array}{r}0.0 \\
671.2 \\
691.8 \\
\\
0.0 \\
259.7 \\
\\
0.0 \\
344.7 \\
\\
229.3 \\
97.4 \\
\end{array}$ & $\begin{array}{r}0.0 \\
511.3 \\
527.0 \\
\\
0.0 \\
197.8 \\
\\
0.0 \\
262.6 \\
\\
174.7 \\
74.2 \\
\end{array}$ & $\begin{array}{r}112.1 \\
540.1 \\
344.7 \\
64.1 \\
193.9 \\
\\
15.6 \\
230.3 \\
\\
143.3 \\
103.4 \\
\end{array}$ & $\begin{array}{r}-60.5 \\
-15.6 \\
+98.5 \\
-34.6 \\
+2.1 \\
\\
-8.4 \\
+17.4 \\
+17.0 \\
\\
-15.8 \\
\end{array}$ \\
\hline Total & 2315.6 & 1747.6 & 1747.6 & 0.0 \\
\hline
\end{tabular}

Note: Equilibrium permit price $=$ US $\$ 540 /$ tonne of $\mathrm{SO}_{2}$ 
by 95 percent for urban salary and wageearning households, 75 percent for rural households, and 80 percent for retired individuals. After 2000 the expenditure share impacts decline steadily. In comparison to these increases, the increases from all the environmental policies are calculated to be nugatory (at most an additional percentage point for rural households and retired persons in the case of the large coal tax).

The impacts of different emission reduction strategies on the coal industry merit special attention, given its political and social significance. As seen in Table A2.14, there is some reduction in coal production with all the policies relative to BASE in 1995, although the BASE production level is achieved by
2010 under CAC, EEC, ETAX1 and SO2TR. However, the main impact on coal production comes from general economic restructuring and energy price reforms. Coal use dropped sharply between 1988 and 1990, and while it recovers somewhat in the BASE case, it does not retum to the 1988 level even by 2010 . Several of the policy scenarios further depress coal production, but generally only by modest amounts (the maximum being four percent in 1995 in FRRED). The major reason for this is that the shortfall in domestic coal and lignite demand is largely offset by expons of hard coal. Hence, even a 100 percent coal tax, which generates revenues of US\$2.8-3.6 billion per annum from 1995, causes coal production to fall by only about 2 percent. 


\section{Chapter 6}

\section{INSTITUTIONAL ISSUES}

The simulation results in Chapter 5 suggest that there are potential savings worth pursuing in using incentive-based control policies. This finding echoes much of the previous work on environmental policy design in the US and other advanced countries, where the potential savings appear to be even larger, given the inefficiencies engendered by rigid technology-based standards. ${ }^{36}$ Nevertheless, the actual advantages of incentive-based policies may fall considerably short of the theoretical ideal, because of technical problems in structuring such policies, and compromises struck to address political concems.

In Chapter 6, we explore this set of institutional issues to see how they condition recommendations for air pollution policy in Poland. We first briefly describe the existing statutory, institutional, and monitoring apparatus in Poland. We then lay out a set of general criteria for evaluating policy designs - CAC, charges, and emissions trading. Using these criteria, we contrast the performance of these three strategies.

\footnotetext{
${ }^{36}$ A survey by Tietenberg ( 1990 ) reveals that rigid policies for air pollution control were likely to cost 2 20 times as much as ideal least-cost control measures. Even with less than ideal incentive-based policies. estimated cost savings are impressive (Hahn and Hester 1989). Note that most of these studies have been concerned with meeting ambient standards rather than the emissions standards of concern here. With ambient standards, total abatement cost can be reduced further by allowing relatively larger emissions in locations where the standards are not binding. By construction, these savings are ruled out in our study.
}

\section{INSTITUTIONAL BACKGROUND ${ }^{37}$}

The February 1990 Ordinance sets ambient air quality standards which, as already noted. are generally tighter than in the West. Energy combustion sources, with installations exceeding $200 \mathrm{~kW}$, face emission standards as well (see Chapter 4). Both ambient and emission standards are set nationally and cannot be strengthened by local authorities, except by declaring a whole region to be a "specially protected" area-a costly option for the locality.

The State Inspectorate for Environmental Piutection-an autonomous unit reporting directly to the Environment Minister-has the task of monitoring both discharges and ambient conditions. Most of the work is done by Inspectorate officers and laboratories at the voivodship (provincial) level. Under the 1990 Ordinance, high emitters (more than $1200 \mathrm{~kg} \mathrm{SO} 2$, more than $800 \mathrm{~kg}$ dust) must continuously monitor their own emissions. Some monitoring also is done by the state Sanitary Engineering Bureau, which helps maintain monitoring sites.

Monitoring occurs at three spatial levels. First, a state system tracks broad trends in $\mathrm{SO}_{2}, \mathrm{NO}_{\mathrm{x}}$ and $\mathrm{PM}$ based on results from about 70 sites throughout Poland, paid for by the state budget. Second, voivodship monitoring often is done in cooperation with heavy polluters mentioned above. Third, at the local level, some factories monitor toxics and metals discharges on instruction from the voivodship.

\footnotetext{
${ }^{37}$ The material in this section is based in part on interviews with members of the Ministry of Environment and the State Inspectorale for Environmental Protection.
} 
Compliance responsibilities and efforts. are divided between voivodship offices of the State Inspectorate, which monitor to check compliance and compute pollution charges, and the voivodship offices of water and environmental management, which issue permits and collect fees and fines. Permits specify discharge levels (the maximum permitted, and the average and annual discharges permitted) and the use of particular abatement measures (e.g., chimney height and diameter) whose installation is monitored by the Inspectorate. The permits are based on air dispersion modeling of the impact of emissions on air quality, carried out by private companies, which must follow strict guidelines. If the estimated pollutants at specified locations, as calculated by the model. exceed the regulations, action will be required before a permit is issued to the emitter (e.g., raising the chimney height). Polluters can argue for higher emission limits by recalculating projected ambient effects.

Fees for "regular" emission levels within the permit are codified in the current ordinance and adjusted for inflation. Fines are based on a half-hour "violation episode" and are paid based on amount of measured exceedance and time $(\$ / \mathrm{kg} / \mathrm{hr})$ until the polluter can prove compliance has been reestablished. Flagrant violation-such as clearly not having functional abatement equipment - can lead to partial or total plant closure and misdemeanor criminal proceedings against the operator, but this is rarely done. Some level of informal regulation also occurs, based on negotiation e.g., permits are issued and fines are calculated at the same time where meeting the standards clearly is impossible. In some cases, however, the emissions are too high to issue a permit and the regulator simply has no leverage over the plant, which keeps operating.
Table 5.4 compares the emission taxes needed to attain projected future emission standards with the actual structure of Polish fees. The sharp increase in fees between 1990 and 1993 is widely believed to have stimulated emission reductions, but the amount of emission reduction due to the fee increases versus general economic restructuring remains unclear (exceptions to fines and standards in enforcement contribute to this identification problem). Current fees apparently are too low to bring total emissions to levels envisaged in the 1990 Ordinance, however. Recent legal actions also call into question the legality of regionally differentiated fees (as opposed to standards) in order to encourage the greatest abatement in areas of high damage (Zylicz 1992).

Apparently the Ordinance currently is being interpreted to allow an emission-control "bubble" over a whole plant (groups of stacks). ${ }^{38}$ However, emissions trading among plants is not permitted under the present law. even at a very local level. New air pollution legislation currently under consideration may provide some encouragement for local trading. More interregional trades among large sources also are conceivable. provided local ambient standards are not breached.

\section{THE EFFECT OF RESTRUCTURING; ON ECONOMIC INCENTIVES}

Important changes in economic policy. which started to take place in Poland after 1988, are expected to transform the way in which polluters respond to economic incentives. In the past, a central planning approach to resource allocation, relying extensively on physical planning targets combined with soft-budget constraints. seriously undermined environmental

\footnotetext{
${ }^{38}$ Personal communication, Professor Tomasz Zylicz. 9 March 1993.
} 
policy. 39 As argued by Zylicz (1993), "financial instruments were doomed to failure in an economy where all essential inputs were allocated administratively, and plant managers had little incentive to pay attention to price stimuli." However, recent reforms in the enterprise and banking sectors are resulting in a hardening of budget constraints and an improvement in resolice utilization. Furthermore, the privatization of large segments of the Polish economy is introducing more effective property rights, a pre-condition for medium- to long-term productivity gains.

An carly attempt at restructuring the Polish economy was taken with the Law on Joint Ventures, in December 1988. The Law had some limited success, and a number of joint ventures were formed in the following two years, but the Govemment of Poland took a major first step toward full-fledged privatization in 1990, when it initiated an Economic Transformation Program (ETP). The ETP led to the rapid privatization of many small enterprises, although the pace was slower than initially expected for the State Owned Enterprises (SOEs) (Kharas 1991). Problems have been caused by the recession, which followed the introduction of the ETP, and by the simultaneous collapse of trading arrangements linked to the Council of Mutual Economic Assistance (CMEA). Furthermore, the process of privatization proved to be much more complex and lengthy than initially expected. In light of these and other factors, the Government has developed an Enterprise and Bank Restructuring Program (EBRP). The EBRP will simultaneously address the inter-related problems of the SOEs, which are not servicing their debts, and of the commercial banks. The EBRP contains additional

39 A discussion of the effect of soft budgets in a central planning regime can be found in Komai (1992). measures designed to facilitate the restructuring of enterprises, using the stateowned commercial banks as key agents of change. Given the fundamental role to be assumed by the banks, the EBRP also aims at stimulating their efficiency, including (ultimately) privatization. A crucial outcome of the EBRP will be further movement from soft to hard budgets, in both the enterprise and banking sectors.

Despite these changes, it is obvious that SOEs will continue to be major players in the Polish economy, at least in the medium term. In that context, there is encouraging evidence that firms are becoming more cost conscious. A recent survey of 75 large state-owned manufacturing enterprises (Pinto, Belka and Krajewski 1993; Hume and Pinto 1993) shows that, even without privatization, SOEs are adjusting, restructuring and increasing profitability in response to the ETP. Of particular relevance is the finding that, "all firms managed to reduce the consumption of materials and energy per unit of sales" (Hume and Pinto 1993, p. 19). Specifically. the 31 best companies reduced energy and material consumption by 22 percent between 1991-92, and the remaining ones by approximately 17 percent (Hume and Pinto 1993).

While these profound changes in economic policy are already in train, and beneficial results are discemible, the timing and speed of further change are matters of considerable uncertainty in Poland, as in the other economies in transition. The effects of decades of central planning will take years to attenuate. Nevertheless, the progress to date gives grounds for optimism that, in the period 1995-2000, restructuring and energy pricing reform will have proceeded far enough to justify the assumptions underlying the scenarios and simulation results discussed in Chapters 4 and 5. From the standpoint of actually designing environmental policies, 
the reforms make it realistic to sericusly consider incentive-based measures.

\section{CONSIDIREATIONS FOR POLICY FVAIIIATION}

Economic elficiency is the criterion most commonly invoked in comparisons of CAC with incentive-based policies. There are, however, other imporant criteria as well. The following points are grouped into two broid categories: those related in legal and technical features, and those relate. to equity and other political economy concems (see also Tripp and Dudek 1989).

Regarding legal and technical features, prospects for success with environmental policies are enhanced if there is a ctear legal authority for taking action; the goals of policy are clearly stated; the effects of policy are consistent with those goals; there is adequate capacity for monitoring effects of the policy measures; and the regulatory authorities possess both the technical capacity to interpret the evidence and the capacity to enforce compliance. Regarding the political economy issues, environmental policy is more likely to succeed if the overall opportunity cost to society is kept as small as possible (given the environmental objectives); and the pc - $y$ does not create a large constituency of o) sition because of adverse distributional ef1 s or other factors that make private con iance costs high. A successful outcome is als more likely if there is greater flexibility for individual actors in the means of compliance, across sources and regions; and procedural obstacles that give rise to high "transaction costs" for compliance are limited. Other important factors, particularly for a transitional economy like Poland, are robustness in the face of imperfect, evolving market institutions and incentives for costreducing innovations in products and processes.
Finally, an evaluation of environmental policies in an open economy like Poland's must consider the consistency between overall national interests and the policies of other countries. Different environmental policies will have different effects on relarive product prices and the terms of trade. These effects will depend in part on the policies pursued by other countries. With these points in mind, we now consider $\mathrm{CAC}$, pollution charges, and tradeable permit policies in tum.

\section{Command and Control}

There is a legal basis for the current system of air emission and ambient standards for stationary sources, though there is some doubt about the consistency of the two standards. Further legislation would be needed to pursue measures such as fuel restrictions on households (e.g., an urban coal use ban) or new controls in the transpor sector (e.g., catalytic converters). As described above, monitoring capacity is in place and improving. The technical capacity of the regulatory authorities also is growing. The legal system is theoretically capable of enforcing standards, but such enforcement in practice is often weak, partly because of unwillingness to deal with the social consequences of shutting down emission sources and causing significant economic dislocations.

Poland also is like many countries in that its environmental goals, and their relationship to current CAC policies, are not entirely clear. The emission standards are meant to contribute to the achievement of ambient targets, but the latter usually take priority. ${ }^{40}$ It is conceivable that under the

\footnotetext{
${ }^{40} \mathrm{~A}$ larger question beyond our scope coocerns the ambient standards themselves. These standands should be set to reflect estimated or suspected damages to human health, investment capital, historic arifacts, and natural systems. However, the absolute
} 
emission standards, some sources would have to overcontrol relative to the abatement necessary to meet ambient standards; or sources could face control requirements in excess of the emission standards to meet ambient limits. A technical difficulty arises here in defining the level of "background" emissions used to calculate a source's impact on ambient conditions. It is not clear that these "background" emissions are properly measured (to exclude the inpact of the source itself); but in any case, in a situation where ambient standards are already violated, it is accepted that a source will still be perminted to operate, provided its excess emissions are less than 20 percent of the standard on a 30 -minute basis.

Although the social cost of CAC is higher than more cost-effective outcomes, as noted previously, the effect is somewhat muted by the fact the Polish CAC is less rigid than purely sechnology-based standards; Polish sources have more choice in abatement options, and some intraplant emission trading among sources appears to be feasible. The current system leaves relatively undisturbed the set of status quo interests in use of the environment as waste sink (e.g., more stringent controls are imposed on new sources), so there is no automatic constituency among polluters in favor of change. In fact, as noted above, the primary constituency is in favor of weakening standards where short-term adjustment costs are high. The CAC approach also is compatible with existing policies in the countries of the EC, notwithstanding acknowledgment by those countries that incentive-based policies can be more costeffective than CAC methods for air pollution control. As discussed below, incentive-based

and relative magnitudes of these changes, both locally and nationally, remain controversial; and as noted previously. Polish standards are very tight compared to Westem norms. policies may have greater effects on product prices and terms of trade than CAC, even though the incentive-based policies are more cost-effective. In this situation, unilateral adoption of incentive-based policies in Poland could create competitive disadvaniages vis-avis other trading partners that would be vexing ror Poland's struggling economy. ${ }^{41}$

\section{Emission Fees}

The legal basis for emission fees in Poland is well established. Fees are levied directly on monitored sources and indirectly on motor fuels (Zylicz 1993). This point is important, since the use of energy taxes based on relative pollution content may be a useful practical strategy where direct monitoring and charging for emissions is problematic. The existing system for monitoring compliance with standards also allows fees to be estimated. Enforcement if the fees has been more problematic, particularly recently, when there were substantial dislocations in the economy and fees rose sharply. Success in using higher fees as an enforcement tool will be limited if there are frequent waivers or subsidies from public budgets. However, this problem is not unique to emission fees; weak environmental enforcement also undercuts CAC.

The distinction between pollution charges as revenue-raisers and fees as enforcement tools needs to be emphasized. In Poland, as in many West European countries, fees contribute to govermment revenue that can be used for meeting urgent social needs in the cleanup of extant environmental damage (thereby strengthening incentives for actually collecting the fees). This purpose is fundamentally different from the use of emission fees as enforcement tools,

\footnotetext{
${ }^{41}$ Even for nontraded goods like electricity and district heat, indirect trade effects through prices of other commodities could be significant.
} 
where the charge rates are higher and the goal of policy is to shrink the "revenue base." Raising revenue for ameliorating past environmental neglect also differs substantially from the use of fee receipts for subsidizing new pollution control efforts. While there is understandably a constituency for the latter application of fee proceeds, such effors risk continuing or aggravating problems of economic restructuring (i.e., the need to move toward hard budgets), and they can undercut the incentives for costminimization that make emission charges more cost-effective than CAC.

Emission fees not only can promote flexibility in compliance strategies but also can induce innovation in pollution reduction, since even sources in compliance will have an incentive to reduce their tax liability. Fees also can be applied even in noncompetitive markets, an important consideration in Poland's transitional economy. When firms can exercise market power, the costeffectiveness of a pollution tax must be balanced against the impact of a tax in further restricting output below competitive levels. However, a more complicated problem arises when firms have weak incentives to minimize costs (Oates and Strassmann 1984). In the Polish context, this can arise because of direct subsidies, soft finance windows for control investments, or direct government intervention in enterprise operation. Again, however, these conditions also will hamper CAC.

There are several aspects of fees that argue against their use as a primary enforcement tool. Their use requires the capacity to index against inflation and to raise fees as economic growth engenders pollution increases. Because fees do not provide the assurance of standards in limiting total emissions, it is doubtful in practice whether fees would ever replace standards. However, the effect of a binding pollution standard, while assuring environmental conditions, is to weaken the cost-effectiveness of the fee approach. ${ }^{42}$

Stiff fees also create an automatic constituency against their use by charging polluters for all emissions, not just emissions in excess of the standards. In this situation, private compliance costs may exceed the CAC level for many polluters, even if social compliance costs (net of tax) are reduced. ${ }^{43}$ The problem is magnified when trading parmers use CAC and their product prices thus do not include the charges on residual emissions. In this case emission fees can create domestic opposition based on trade disadvantages, since the fees raise the relative cost of domestic exports to foreign buyers. ${ }^{\text {th }}$

Finally, it should be noted that, in order to meet ambient standards as well as source emission standards in a cost-effective way. fees have to be differentiated across sources and regions to reflect the differing contributions of sources to ambient conditions and the divergence among regions in excess emissions. Clearly, setting uniform fees high enough to meet the most stringent ambient standard in the most polluted region would involve significant overcontrol elsewhere. At a minimum, some "zoning" of fees locally and regionally is needed to contribute to effective attainment of ambient standards. However, differential fees are currently not admissible, as nnted above.

\footnotetext{
${ }^{42}$ While fees cannot assure emissions, they do put an upper bound on the marginal abatement costs firms will undertake. This is a useful escape valve against excessive abatement expenditures.

${ }^{43}$ Chapter 5 reports the ag gregate financial burden in our two tax scenarios. ETAX1 and ETAX2.

${ }^{44}$ See Burtraw (1993) for further discussion.

Conversely, attempts to maintain emission fees below: ievels in some Westem European countries could become a bone of contention with trading partners.
} 


\section{Emission Trading}

The legal status of emission trading is the least clear of the strategies we are considering. As noted above, air pollution legislation currentiy under consideration is understood to include a clarification of how individual polluting entities might trade off controls on their own contiguous sources (e.g., controls on multiple sources within the same power or steel plant). The scope for trading among nearby sources might also be increased. However, regional-scale trading, as in the 1990 U.S. Clean Air Act Amendments authorizing $\mathrm{SO}_{2}$ trading, seems to be a more distant prospect.

Emission trading also will put some additional operational and monitoring burdens on regulators. The extent of these burdens depends on the scale of trading. For a fullblown permit market with many participants, a formal exchange system must evolve and continuous monitoring may be needed to ensure the integrity of trades. For more informal "swaps" of control responsibility among individual polluters the regulatory burden will not be as large, though it is still necessary to ensure that violation of the standard by one polluter is matched by overcontrol on the part of another polluter.

To better understand the prospects for success with emission trading in Poland, it is important to keep in mind that the textbook model of an organized, competitive permit market is one end of a continuum. At the other end is intraplant trading across sources by a firm (or other entity), and in between are informal bilateral trades of various types. ${ }^{45}$

\footnotetext{
${ }^{45}$ Emission trading under the U.S. Clean Air Act has included "netuing," "offsets," and "bubbles." Netting allows a firm creating a new discharge source to avoid stringent new source performance standards if it reduces emissions from other plant sources. Netting is always an intemal trade. Offsets allow new sources to enter "non-attainment areas" if they reduce existing source emissions by an even greater
}

Depending on the structure of the program, such trades can hold total emissions constant or require a net reduction of emissions to improve air quality. Internal or extemal trades also can occur over time, as unused emission permits are accumulated and subsequently used, a process known as "banking."

Difficulties in organizing emission trading arise in connection with the specificity and security of property rights over emission allowances, and with "transaction costs," the general ease or difficulty of effectua:ing transactions. Property rights issues arise. for example, when there is ambiguity in the definition or measurement of baseline emissions against which "excess" control available for sale is reckoned, and when there is ambiguity about the status of banked emission credits. Insecurity about property rights limit supply and demand for permits and thus the volume of transactions. High transaction costs that also limit trading can arise from onerous approval procedures for trades or requirements that transactions reduce net emissions (a form of transactions $\operatorname{tax}$ ).

In addition to reducing overall trading. such obstacles bias emission transactions in favor of intemal trading, where difficulties in identifying transaction partners, securing property rights, and compleing trades are smaller. As a consequence, some costeffective extemal trades are missed. ${ }^{46}$ This

amount. Offsets can involve intemal and extemal trades. Bubbles are aggregations of pollution from all sources in a particular plant or area that require control only on the aggregates, rather than on individual source emissions. Bubbles also can involve internal or external crades: of the three options listed here, they come closest to the textbook description of emission trading. For further discussion see Hahn and Hester (1989) and Tietenberg (1985, 1990).

46 The survey by Hahn and Hester (1989) documents the predominance of internal trades in the U.S. Clean 
point has been emphasized by Atkinson and Tietenberg (1991), who argue that bubble transactions in the US emissions trading program have been bilateral and sequential, rather than the multilateral simultaneous exchanges needed to arrive at an efficient outcome. However, a significant part of this trading inefficiency may stem from regulatory policies that hinder the actions of selfinterested parties in developing better informational and trading institutions with lower transaction costs.

Concerms over both property rights and transaction costs stem in part from conflicts between environmental objectives (improved air quality) and holding down compliance cost burdens. This tension is manifested in, for example, wrangling over emission baselines and regulatory checks on trades. Such conflict is particularly important to keep in mind in considering the Polish situation, where there are strong desires both to hold down compliance costs and to improve air quality. ${ }^{47}$

Emission trading also may fail to achieve its theoretical potential because of distortions caused by market power over emission allowances or by regulation of firms' product output and pricing decisions (as in the public utility sector). A firm with market power over permits could distort the allocation of permits among other existing polluters and encumber entry of efficient competitors in its product markets (Hahn

\footnotetext{
Air Act program and provides several explanations based on property rights and transaction cost concerns. Tietenberg (1990) cites evidence that potential cost savings under emissions tradiog may be significant even with internal trading alone, but there nonetheless appears to be a substantial loss of costeffectiveness from constraints on external trading. ${ }^{47}$ See also Oates, Portney and McGartland (1989) who argue that some nominal overcontrol under CAC may not be a social burden because aggregare pollution reduction below prevailing standards is justified in light of the damages caused.
}

1984). However, research to date suggests that even fairly "thin" permit markets could be relatively efficient, and that significant market power over permits is relatively unlikely if permits initially are widely distributed based on historical emissions (Tietenberg 1990).

A bigger issue is regulation of production and pricing decisions by private or state-owned firms that leads such firms awny from socially cost-minimizing decisions. Regulatory distortions will occur, for example, if firms face favorable regulatory or tax treatment of compliance expenditures relative to expenditures on emission allowances. This is an especially serious problem in regulating emissions from the electric power sector, where government intervention is likely to remain ubiquitous even after economic restructuring. ${ }^{40}$

Another important institutional difficulty in establishing emission trading (and charge systems) relates to the nature of different pollutants in the atmosphere. The ultimate goal of pollutant control is improving ambient air quality. When pollutants $\mathrm{mix}$ relatively uniformly over medium to large areas, the location of individual emissions is not that important in determining overall air quality. Emission permits supplied and demanded by dispersed polluters can be treated as interchangeable. Policy in these cases can focus directly on emission control.

In contrast, when pollutants do not mix uniformly, the location of emissions does matter in determining the effect of emission reductions on air quality. In this case, multiple permit systems generally are needed to fully reflect the impacts of particular emissions at different receptor points. Such systems are fairly difficult to structure and costly to implement. Compromises, such as stratifying sources into trading "zones," often

\footnotetext{
${ }^{48}$ See Bohi and Burtraw (1992) for discussion of this issue in the U.S. context.
} 
can significantly limit cost-effectiveness by restricting trading options (see Tietenberg 1985. Chapter 4 and Tietenberg 1990 for further discussion). In practice, trading with non-uniformly mixed pollutants generally involves mostly contiguous sources in order to lessen these challenges. An important exception to this point arises when the target volume of aggregate emission reductions is very large, as in the $\mathrm{US} \mathrm{SO}_{2}$ program. In this case, it is more likely that ambient conditions generally will improve even if emissions are reallocated through trading, and the locations of specific polluters may be less important.

Like emissions taxes, emissions trading will stimulate innovation in pollution reduction. However, this stimulus will be attenuated if trading options are limited. The domestic constimency against emission trading is likely to be weaker than with taxes because the initial endowment of emission rights could be adjusted to address distributionai concems. Nevertheless, emission trading could have intemational trade effects if a sector that is important in trade-for example, a growing sector with few grandfathered emission rights-also must incur significant costs for permit acquisition. 45 Balanced against this effect, on the other hand, is the very real possibility of cost savings because of the flexibility embodied in emissions trading.

It is important to note again that many of the difficulties with emission tradingmonitoring, verifying trades, guarding against market power, reconciling emission controls with ambient air conditions-are mnst serious for full-blown permit trading on a wide scale and may be less sericus in more limited transactions. Such transactions are less effective in exploiting all gains from trade, but

\footnotetext{
${ }^{49}$ The same may be true even for sectris with large permit endowments if the opportunity cost of foregone permit sales is rolled into product prices.
}

the important point is that they can exploit some gains. Many of the obstacles to ialing in past US experience appear to have bee.1 regulatory rather than intrirsic and thus could be avoided by regulators in Poland. ${ }^{30}$

The argument for at least limited trading is supported by experience from the attempt to institute trading on an experimental basis in Chorzow, a ciry in Upper Silesia (Dudek, Kulczynski, and Zylicz 1992). In Chorzow, significant pollution is caused by both a steel mill and a power plant. The stecl plant already has undertaken some modemization that reduces emissions (closing coke ovens and piping in natural gas). Further contemplated changes (closing of open hearth fumaces) would yield additional pollution reduction. The power plant is far out of compliance and is considering ambitious but expensive modemization (installation of fluidized bed boilers) to meet stricter standards likely to be faced in 1997. Accelerating the power plant modemization would be costly, while reducing is output or closing the plant would have serious social consequences.

Under these circumstances, significant cost savings and more rapid environmental improvement were estimated to be artainable if the power generator financed further abatement at the steelworks. However, proceeding with this plan requires regulators to approve continued operation of the power plant with emission levels in excess of its standard, in a region that already faces serious pollution loadings. Apparently this transaction so far has been blocked by lack of regulatory approval.

\footnotetext{
${ }^{50}$ Emissions trading may actually improve environmental compliance in that some highly polluting firms that might otherwise either close down or emit with impunity, given uneven enforcement of CAC, can finance abatement investments under emissions trading with sales of emission reduction credits that they generate.
} 
The discussion in this chapter has focused on comparing CAC, emission fees, and emission trading. However, it is important not to see the choice of policy instruments as mutually exclusive. All three approaches to pollution control have a role to play. In the next chapter we outline an integrated strategy. 


\section{Chapter 7}

\section{CONCLUDING REMARKS}

The following seem to be among the key points implied by the simulation analysis:

(1) Significant decreases in air pollution emissions are likely from economic restructuring and energy pricing reforms. even without major new environmental initiatives. Nevertheless, tighter (enforced) emission standards such as those envisaged under current Polish policy may generate considerable additional decreases in pollution, particularly $\mathrm{PM}$ and $\mathrm{SO}_{2}$ -

(2) The Polish legal standards differ in important respects from typical West European standards; in particular, Polish PM standards are looser, while Polish $\mathrm{NO}_{x}$ standards are tighter. However, the costs of meeting the two altemative sets of standards in Poland do not appear to be widely different. Thus, cost would not appear to be a major obstacle in switching to standards more closely atruned to the European Community; the larger questions are the capability of meeting any standards as tough as the Polish or EC standards and the willingness to alter emphases on pollutants.

While the Polish and typical EC standards involve roughly comparable costs, the costs of the strict German standards are significantly higher. The size of this extra cost underscores a need for corresponding benefit assessment to determine the value to Poland of such stardards.

(3) There are clear cost savings from using incentive-based policy instruments, even though the exact size of the savings cannot be precisely identified. Even with limited application of taxes or permit trading to large rationaiy sources, cost savings are not trivial. They arise in part from relaxing newsource bias in command approaches. Previous research suggests also that significant savings are possible just from intraplant emission trading, for which the model already allows, even in command-andcontrol cases.

(4) Further savings may be possible by extending incentive-based policies to more decentralized emissions sources in lieu of costly command and control (as in the transpor sector in our study). However, these savings in the scenarios derive partly from eliminating relatively costly pollution control measures (like catalytic converters in our cases) that might not be imposed anyway in a more cost-conscious command-andcontrol policy regime. The comparison of a very costly command-and-control scheme to an ideal set of incentive-based policies probably overstates the benefits of broadening the scope for the latter policies.

(5) As the experiment with a coal tax suggests, pollution control policies and incentives need to be broad-based to make effective headway in reducing emissions at reasonable costs. Focusing on orly a few sources or fuels is likely to have disappointing and expensive results.

(6) Both command and incentive-based policies will require considerable expenditures to achieve the specified standards. However, the impacts on investment and energy prices of environmental policies is likely to be dwarfed by tine forces of economic restructuring and energy price reform that have already been unleashed and that are a 
prerequisite for ultimate success in environmental policy.

\section{POLICY CONSIDERATIONS}

The argument in Chapter 6, coupled with the simulation results, suggests a dynamic and mixed strategy for the choice of economic instruments. If necessary, CAC alone might be relied upon, particularly for houschold and transport sources, where emission trading is costly to arrange and taxes are technically or politically difficult to apply. For larger sources, however, and even for smaller sources where feasible, increased reliance would be placed on economic instruments. These instruments would complement CAC standards rather than substituting for them. In particular, the standards would provide a basis for computing emission fees and for structuring emission trades.

A starting point for the approach we envisage is raising emission fees above current levels. This would encourage some additional abatement and technical innovation, as well as providing added revenues for cleanup of existing environmental damages (or other purposes).
However, for the reasons noted previously it is unlikely that fees will rise to the level necessary to meet current emissions standards. To accomplish this goal costeffectively, an evolutionary movement toward emissions trading among large stationary sources is needed. ${ }^{31}$ Trading could stan with informal bilateral transactions, as in the US, and become more extensive as circumstances and the interests of polluters warrant.52 To accomplish this requires in turn a clearer legal and regulatory authority for emission trading, as well as continued progress in economic restructuring so that firms have incentives to seek out lower-cost abatement options.

We emphasize again the importance of continued progress in economic and energy price reform as both a complement to and a prerequisite for success in environmental policy. In particular, it is likely to be the case that greater reliance on incentive-based policies will require further maturation of the economic system in Poland-continued reduction of direct and indirect subsidies, and in direct enterprise decisionmaking by government. Without such progress, effective enforcement of command-based approaches also will face serious roadblocks.

\footnotetext{
SI Note that when fees and permits are used in tandem, an increase in the former lowers the value of the lanter and causes permit prices to fall an equal amount.

52There may also be scope for trading between point and nonpoint sources, as is currently being attempled experimentally in the US (e.g., the retirement of old vehicles in Califomia).
} 


\section{REFERENCES}

Atkinson, S. and T. Tietenberg. 1991. "Market Failure in Incentive-Based Regulation: The Case of Emissions Trading," Journal of Environmental Economics and Management vol. 21, no. 1 (July), pp. 17-31.

Bates, R. W. and E. A. Moore. 1992. "Commercial Energy Efficiency and the Environment." Background Paper for World Development Report 1992, Policy Research Working Papers WPS 972 (Washington, DC, The World Bank, September).

Bohi, D. R. 1981. Analyzing Demand Behavior: A Study of Energy Elasricities (Washington, DC, Resources for the Future).

Bohi, D. R. and D. Burtraw. 1992. "Utility Investment Behavior and the Emission Trading Market," Resources and Energy vol. 14, nos. 1/2 (April), pp. 129-156.

Bojarski, W., et al. 1992. "Poland - Energy Policy and Energy Program up to the Year 2010" (Warsaw, Ministry of Industry and Trade, ZPE IPPT-PAN).

Bolek, K. and J. Wertz. 1992. "Environmental Protection in Cracow Region" (Cracow).

Borenstein, S. 1988. "On the Efficiency of Competitive Markets for Operating Licenses," The Quarterly Journal of Economics vol. 103, no. 2 (May), pp. 357-385.
Burtraw, D. 1993. "The Promise and Prospect for $\mathrm{SO}_{2}$ Emission Trading in Europe." RFF Discussion Paper QE9322 (Washington, DC, Resources for the Future).

Central Statistical Office. 1991. Ochrona Srodowiska 1991 (Warsaw, Glowny Urzad Starystyczny).

Central Statistical Office. 1992. Ochrona Srodowiska 1992 (Warsaw, Glowny Urzad Statystyczny).

Cochran, L. S. and R. A. Pielki. 1992. "Selected Intemational Receptor-Based Air Quality Standards," Journal of Air and Waste Management Association vol. 42, no. 12 (December), pp. 15671572.

Cofala, J. 1985. "A Model of the Polish Energy System," in A. S. Kydes and D. M. Geragy, eds., Energy Markets in the Longer-Term: Planning under Uncertainty (Amsterdam, Elsevier Science Publishers, North-Holland).

Cofala, J., H. W. Balandynowicz, and Z. Parczewski. 1990. "Scenarios of Energy and Environment Future for Poland," in Proceedings: Seminar on Energy in East and West: The Polish Case (Paris, OECD), pp. 403-426.

Coopers \& Lybrand Deloitte. 1991. Environmental Assessment of the Gas Development Plan for Poland (World Bank/UNDP/Bilateral Aid Energy Sector Management Assistance Program). 
Dowlatabadi, H. and M. A. Toman. 1991. Technology Options for Electricity Generation (Washington, DC, Resources for the Future).

Dudek, D., Kulczynski, Z., and T. Zylicz. 1992. "Implementing Tradable Rights in Pciand: A Case Study of Chorzow." Paper presented at the European Association of Environmental and Resource Economists Third Annual Conference, Cracow, June 16-19.

Hahn, R. W. 1984. "Market Power and Transferable Property Rights," The Quarterly Journal of Economics vol. 99. no. 4 (November), pp. 753-765.

Hahn, R. W. and G. L. Hester. 1989. "Where Did All the Markets Go? An Analysis of EPA's Emissions Trading Program," Yale Journal on Regulation vol. 6, no. 1, pp. 109-153.

Hume, I. M., and B. Pinto. 1993. "Prejudice and Fact in Poland's Industrial Transformation," Finance and Development vol. 30, no. 2 (June), pp. 18-20.

Intemational Energy Agency. 1990. "Energy Policies, Poland, a Survey," (Paris, OECD/IEA).

Kharas, H. J. 1991. "Restructuring Socialist Industry: Poland's Experience in 1990." World Bank Discussion Paper No. 142 (Washington, DC, The World Bank).

Kornai, J. 1992. The Socialist System: The Political Economy of Communism (Princeton, NJ, Princeton University Press).
Krupnick, A., K. Harrison, E. Nickell and M. Toman. 1993. "The Benefits of Ambient Air Quality Improvements in Central and Eastern Europe: A Preliminary Assessment." RFF Discussion Paper ENR93-19 (Washington, DC, Resources for the Future).

Ministry of Environmental Protection, Natural Resources and Forestry. 1991. The State of the Environment in Poland: Damage and Remedy (Warsaw, Ministry of Environmental Protection, Natural Resources and Forestry).

Nowicki, M. 1992. Environment in Poland: Issues and Solutions (Warsaw, Ministry of Environmental Protection, Natural Resources and Forestry).

Nowicki, M. 1993. Environment in Poland: Issues and Solutions (Dordrecht, Kluwer).

Oates, W. E. and D. L. Strassmann. 1984. "Effluent Fees and Market Structure," Journal of Public Economics vol. 24, no. 1, pp. 29-46.

Oates, W., P. Portney, and A. McGartland. 1989. "The Net Benefits of IncentiveBased Regulation: A. Case Study of Environmental Standard-Setting," American Economic Review vol. 79, no.5 (December), pp. 1233-1242.

Pearce, W. D. and R. K. Tumer. 1990. Economics of Natural Resources and the Environment (Baltimore, Johns Hopkins University Press). 
Pezzey, J. 1992. "The Symmetry Between Controlling Pollution by Price and Controlling ilt by Quantity. Canadian Journal of Economics vol. 25, no. 4 (November), pp. 983-991.

Pinto, B., M. Belka and S. Krajewski. 1993. "Transforming State Enterprises in Poland: Microeconomic Evidence on Adjustment." World Bank, Policy Research Working Paper Series No. 1101 (Washington, DC. The World Bank).

Rollo J. M. C. and J. Stern. 1992. "Growth and Trade Prospects for Central and Eastern Europe." Working Paper No. 1 (London, National Economic Research Associates (NERA).

Sierpinska, M. 1991. "The Necessity of Introducing Raw-Material Saving and Energy-Saving Projects to Polish Industry," in $\mathbf{K}$. Gorka, ed., Environmental and Economic Aspects of Industrial Development in Poland: Selected Papers (Krakow, Krakow Academy of Economics).

Tietenberg, T. H. 1985. Emissions Trading: An Exercise in Reforming Pollution Policy (Washington, DC, Resources for the Future).

Tietenberg, T. H. 1990. "Economic Instruments for Environmental Regulation," Oxford Review of Economic Policy vol. 6, no. 1 (Spring).

Tietenberg, T. H. 1992. Environmental and Natural Resource Economics, 3rd ed. (New York, Harper Collins).

Tripp, J. T. B. and D. J. Dudek. 1989. "Institutional Guidelines for Designing
Successful Transferable Rights Programs," Yale Journal on Regulation vol. 6, no. 2 (Summer), pp. 369-392.

United Nations Environment Program. 1992. Saving Our Planet: Challenges and Hopes (Nairobi, UNEP).

Walls, M. A. 1993. "Motor Vehicles and Pollution in Central and Eastem Europe." RFF Discussion Paper ENR93-22 (Washington, DC, Resources for the Future).

Wasikiewicz, U. 1991. "Changes in Polish Energy Policy to Decrease Environmental Pollution," in K. Gorka, ed., Environmental and Economic Aspects of Industrial Development in Poland: Selected Papers (Krakow, Krakow Academy of Economics).

Weitzman, M. L. 1974. "Prices vs. Quantities," Review of Economic Studies vol. 41, no. 4 (October), pp. 477-491.

World Resources Institute. 1992. World Resources 1992-93 (New York, Oxford University Press).

Zylicz, T. 1992. "Environmental Taxes in Poland," Drafi Manuscript (Warsaw, Ministry of the Environment).

Zylicz, T. 1993. "Case Study on Poland." Paper presented to the OECD Workshop on Taxation and Environment in European Economies in Transition, Paris, 25-26 February. 
Appendix 1:

Details on the Modeling Scenario Definitions 
Table A1.1. Economic Growth and Structural Change to 2010 (1990 prices)

\begin{tabular}{|l|r|r|r|r|r|}
\hline Category & 1988 & 1990 & 1995 & 2000 & 2010 \\
\hline Population (millions) & $3 \% .9$ & 38.2 & 38.8 & 39.5 & 41.0 \\
& & & & & \\
Gross National Product (GNP) & & & & & \\
- Trillions of zloty & 685 & 607 & 634 & 798 & 1181 \\
- Index (1990=100) & 113 & 100 & 105 & 132 & 195 \\
Contribution to GNP (\%) & & & & & \\
- Energy industry & 6.1 & 6.9 & 7.7 & 7.2 & 5.6 \\
- Total industry (incl. energy) & 52.2 & 46.1 & 44.7 & 42.8 & 39.7 \\
- Construction & 8.8 & 8.7 & 8.7 & 8.2 & 7.0 \\
- Agriculture & 6.1 & 7.1 & 6.8 & 5.8 & 4.9 \\
- Transport & 3.9 & 3.9 & 3.9 & 3.9 & 4.2 \\
- Other & 29.0 & 34.2 & 35.8 & 39.2 & 44.2 \\
\hline
\end{tabular}

Table A1.2. Production of Energy-Intensive Products and Services

\begin{tabular}{|c|c|c|c|c|c|}
\hline Product/service & 1988 & 1990 & 1995 & 2000 & 2010 \\
\hline Pig iron ( $10^{3}$ tonnes) & 10260 & 8400 & 7850 & 7800 & 7650 \\
\hline Steel (10 $0^{3}$ tonnes) & 16870 & 13450 & 11200 & 12550 & 12400 \\
\hline Copper ( $10^{3}$ tonnes) & 401 & 346 & 375 & 390 & 450 \\
\hline Aluminum $\left(10^{3}\right.$ tonnes $)$ & 48 & 47 & 48 & 49 & 50 \\
\hline Sulphur (103 tonnes) & 5000 & 4696 & 4900 & 4900 & 5070 \\
\hline Ammonia $\left(10^{3}\right.$ tonnes) & 2340 & 1580 & 2150 & 2500 & 2600 \\
\hline 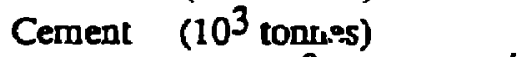 & 17000 & 12500 & 13600 & 15020 & 16000 \\
\hline Freight transp. $\left(10^{9} \text { in une-km }\right)^{\mathrm{a} /}$ & 144 & 97 & 107 & 125 & 164 \\
\hline Dwellings $\left(10^{3}\right)$ & & & & & \\
\hline - newbil & 0 & 0 & 650 & 1400 & 4600 \\
\hline - retrofitted $\mathrm{b} /$ & $\mathbf{0}$ & 0 & 880 & 2200 & 6050 \\
\hline - Total & 10925 & 11180 & 11730 & 12360 & 15310 \\
\hline Private cars $\left(10^{6}\right)$ & 4.5 & 5.3 & 6.0 & 6.8 & 8.8 \\
\hline
\end{tabular}

a/only professional land transport included

b/since 1990 
Table A13. International Fuel Pricesa/ (USS/unit)

\begin{tabular}{|l|c|c|c|c|c|c|}
\hline Fuel & Unit & 1990 & 1995 & 2000 & 2005 & 2010 \\
\hline Hard Coal & tceb & & & & & \\
\hline - lump size (export price) & & 51 & 53 & 57 & 59 & 62 \\
- coal fines (export price) & & 47 & 48 & 52 & 55 & 58 \\
- coking coal (export price) & & 53 & 53 & 56 & 59 & 62 \\
- coal fines & & 52 & 54 & 57 & 60 & 62 \\
\hline Natural Gas & $10^{3} \mathrm{~m}^{3}$ & & & & & \\
\hline - pipeline (traditional) & & 100 & 113 & 125 & 131 & 138 \\
- pipeline (new) & & 110 & 124 & 137 & 144 & 152 \\
- LNG & & 144 & 159 & 175 & 185 & 195 \\
\hline Liquid fuels & ton & & & & & \\
\hline - crude oil (heavy) & & 140 & $: 60$ & 180 & 199 & 218 \\
- gasoline & & 240 & 274 & 308 & 343 & 377 \\
- diesel & & 193 & 221 & 248 & 275 & 302 \\
- heavy fuel oil & & 96 & 108 & 119 & 129 & 138 \\
\hline Nuclear fuel & tceb & 24 & 25 & 27 & 27 & 28 \\
\hline
\end{tabular}

a/All import prices are cif for imports except those noted as "export price," which are fob. $\mathrm{b} /$ tonne of coal equivalent

Table. A1.4. Fuel Prices to Final Energy Consumers in BASE Case (US\$/unit)

\begin{tabular}{|l|r|r|r|r|r|}
\hline Fuel & Unit & June '92 & \multicolumn{1}{|c|}{1995} & \multicolumn{1}{|c|}{2000} & 2010 \\
\hline Hard coal & & & & & \\
- to industry & tce & 43 & 52 & 55 & 60 \\
- to households & tce & 76 & 88 & 93 & 98 \\
Natural gas & & & & & \\
- to industry & $10^{3} \mathrm{~m}^{3}$ & 130 & 132 & 144 & 158 \\
- to households & $10^{3} \mathrm{~m}^{3}$ & 160 & 280 & 300 & 310 \\
Gasoline & tonne & 654 & 1033 & 1158 & 1419 \\
Diesel oil & tonne & 395 & 514 & 572 & 703 \\
Fuel oil light & tonne & - & 310 & 347 & 425 \\
Electricity & & & & & \\
- to industry & MWh & 41 & 51 & 52 & 53 \\
- to households & MWh & 42 & 81 & 81 & 82 \\
District heat & GJ & 3.6 & 4.7 & 4.9 & 5.2 \\
- to industry & GJ & 4.2 & 8.4 & 8.7 & 8.9 \\
- to households &
\end{tabular}


Table A1.5. Share of Transmission/Distribution Costs and Taxes in Fuel Prices to Final Consumers in 1995, the BASE Case

\begin{tabular}{|l|c|}
\hline Fuel & Share (\%) \\
\hline Hard coal & \\
- to industry & 20 \\
- to households & 40 \\
Natural gas & \\
- to industry & 10 \\
- to households & 60 \\
Gasoline & 75 \\
Diesel oil & 60 \\
Fuel oil light & 35 \\
Electricity & 30 \\
- to industry & 55 \\
- to households & \\
District heat & 10 \\
- to industry & 50 \\
- to households & \\
\hline
\end{tabular}


Table A1.6. Own Price Elasticities Applied in the Scenarios?

\begin{tabular}{|l|c|c|c|}
\hline Fuel/sector & Industry & Transporta/ & $\begin{array}{c}\text { Residential } \\
\text { Commercial }\end{array}$ \\
\hline Solid fuels & -0.5 & 0 & -0.4 \\
\hline Fuel oil & -1.0 & 0 & -0.4 \\
\hline Motor fuels & -1.0 & -1.0 & -1.0 \\
\hline Gas & -0.5 & 0 & -0.4 \\
\hline Electricity & -0.5 & 0 & -0.5 \\
\hline Heat & -0.5 & 0 & -0.4 \\
\hline
\end{tabular}

$\mathrm{g}$ In the transport sector, it has been assumed that only demand for motor fuels (gasoline and diesel oil) is price elastic. Little hard coal is consumed in this sector; and while electricity is used by railways, electricity costs are a small proportion of total costs, so it has been assumed that no demand adjustment will occur as a result of higher electricity prices due to stricter environmental regulations.

Table A1.7. Polish $\mathrm{SO}_{2}$ Standards

( $g / G J$ fuel input)

\begin{tabular}{lccc} 
Source & A & $\boldsymbol{B}$ & $\boldsymbol{C}$ \\
\hline Coal: & & & \\
- fixed grate & 990 & 720 & 650 \\
- mechanical grate & 990 & 640 & 200 \\
- PF - dry bottom ${ }^{\text {a }}$ & 1240 & 870 & 200 \\
-PF - wet bottom & 1240 & 870 & 200 \\
Lignite: & & & \\
- PF - dry bottom & 1540 & 1070 & 200 \\
- PF - wet bottom & 1540 & 1070 & 200 \\
Coke: & & & \\
- fixed grate & 410 & 410 & 410 \\
- mechanical grate & 500 & 250 & 250 \\
Fuel Oil: & & & \\
- < 50 MW & 1720 & 1250 & 1250 \\
- > 50 MW & 1720 & 170 & 170 \\
\hline
\end{tabular}

a/PF - pulverized fuel

$A=$ interim standards for existing (pre-1994) sources

$B=$ final standards for existing sources

C = standards for new (post-1994) sources 
Table A1.8. Polish $\mathrm{NO}_{\mathrm{x}}$ Standards

(g/GJ fuel input)

\begin{tabular}{lccc} 
Source & $A$ & $B$ & $C$ \\
\hline Coal: & 35 & 35 & 35 \\
- fixed grate & 160 & 95 & 95 \\
- mechanical grate & 330 & 170 & 170 \\
- PF - dry boltom & 495 & 170 & 170 \\
- PF - wet bottom & & & \\
Lignite: & 225 & 150 & 150 \\
- PF - dry boltom & 225 & 150 & 150 \\
- PF - wet bottom & & & \\
Coke: & 45 & 45 & 45 \\
- fixed grate & 145 & 145 & 110 \\
- mechanical grate & & & \\
Fuel Oil: & 120 & 120 & 90 \\
- < 50 MW & 160 & 160 & 120 \\
- > S0 MW & & & \\
Natural Gas: & 60 & 35 & 35 \\
- < S0 MW & 145 & 85 & 85 \\
- > S0 MW & & & \\
Puelwood: & 50 & 50 & 50 \\
- fixed grate & & & \\
\hline
\end{tabular}

See notes for Table A1.7.

Table A1.9. Polish Particulates Standards (g/GJ fuel input)

\begin{tabular}{lccc} 
Source & A & B & C \\
\hline Coal: & & & \\
- fixed grate & 1850 & 1370 & 1370 \\
- mechanical grate & 800 & 600 & 600 \\
- PF - dry bottom & 260 & 130 & 130 \\
- PF - wet bottom & 170 & 90 & 90 \\
Lignite: & & & \\
- PF - dry bottom & 195 & 95 & 95 \\
- PF - wet bottom & 140 & 70 & 70 \\
Coke: & & & 235 \\
- fixed grate & 720 & 235 & 235 \\
- mechanical grate & 310 & 235 & \\
\hline See notes for Table A1.7. & &
\end{tabular}


Table A1.10. European Community $\mathrm{SO}_{2}$ Standards (g/GJ fuel input)

\begin{tabular}{|c|c|c|}
\hline Source & existing & new \\
\hline$>50 \mathrm{MW}_{\mathrm{th}}$ & $\begin{array}{l}25 \% \mathrm{a} / \text { reduction until } 1993 \\
43 \% \mathrm{a} / \text { reduction until } 1995 \\
60 \% \mathrm{a} / \text { reduction until } 2003\end{array}$ & \\
\hline \multicolumn{3}{|l|}{ Coal: } \\
\hline $\begin{array}{c}100-500 \mathrm{MW}_{\text {th }} \\
>500 \mathrm{MW}_{\mathrm{th}}\end{array}$ & & $\begin{array}{l}840.4 \times \mathrm{b} / \\
140\end{array}$ \\
\hline \multicolumn{3}{|l|}{ Fuel Oil: } \\
\hline $50-300 \mathrm{MW}_{\text {th }}$ & & 510 \\
\hline $300-500 \mathrm{MW}_{\text {th }}$ & & $1080-6.5 \times \mathrm{c}$ \\
\hline$>500 \mathrm{MW}_{\mathrm{th}}$ & & 120 \\
\hline \multicolumn{3}{|l|}{ Natural Gas: } \\
\hline$>50 \mathrm{MW}_{\text {th }}$ & & 11 \\
\hline
\end{tabular}

a/compared to 1980

$\mathrm{b} / \mathrm{x}=35$ for each $100 \mathrm{MW}$ th of thermal capacity; e.g., if the thermal capacity is $100 \mathrm{MW}_{\text {th }}$, the corresponding standard is $840-4 * 35=700 \mathrm{~g} / \mathrm{GJ}$

c/as above but for each $100 \mathrm{MW}_{\text {th }} \mathrm{x}=30$; for $100 \mathrm{MW}$ th unit the standard is $1080-6.5 * 30=885 \mathrm{~g} / \mathrm{GJ}$

Table A1.11. European Community $\mathrm{NO}_{\mathrm{x}}$ Standards (g/GJ fuel input)

\begin{tabular}{lll} 
Source & \multicolumn{1}{c}{ existing } & new \\
\hline$>50 \mathrm{MW}_{\text {th }}$ & $20 \% \mathrm{a} /$ reduction until 1993 & \\
$36 \% \mathrm{a}_{\text {reduction until } 1995}$ & \\
Coal: & & $228 \mathrm{~b} /$ \\
$>50 \mathrm{MW}_{\text {th }}$ & \\
Fuel Oil: & 135 \\
$>50 \mathrm{MW}_{\text {th }}$ & \\
$\begin{array}{l}\text { Natural Gas: } \\
>50 \mathrm{MW}_{\text {th }}\end{array}$ & 109 \\
\hline
\end{tabular}

$\underline{a} /$ compared to 1980

$\mathrm{b} /$ for solid fuels with less than $10 \%$ volatile compounds the value is $455 \mathrm{~g} / \mathrm{GJ}$ 
Table A 1.12. European Community Particulates Standards (g/GJ fuel input)

\section{Source}

\begin{aligned} & \hline $50-500 \mathrm{MW}_{\text {th }} 35 \\ &>500 \mathrm{MW}_{\text {th }} 18 \\ &$\hline\end{aligned}

Table A1.13. German $\mathrm{SO}_{2}$ Standards (g/GJ fuel input)

\section{Source}

\begin{tabular}{ll}
\hline Coal & \\
eristing plants (till 1993) & 875 \\
$1-100 \mathrm{MW}_{\text {th, new }}$ & 700 \\
$100-300 \mathrm{MW}_{\text {th }}$, new & 700 and $60 \%$ removal \\
$>300 \mathrm{MW}_{\text {th }}$, new & 140 and $85 \%$ removal \\
$1-300 \mathrm{MW}_{\text {th }}$, FBC & 140 or $75 \%$ removal \\
Fuel Oil: & \\
$1-5 \mathrm{MW}_{\text {th }}$ & light fuel oil only \\
$5-100 \mathrm{MW}_{\text {th }}$ & 510 \\
$100-300 \mathrm{MW}$ th & 510 and $60 \%$ removal \\
$>300 \mathrm{MW}$ th & 120 and $85 \%$ removal \\
Gas: & 11 \\
Natural gas & 31 \\
Coking $\&-$ Refinery gas &
\end{tabular}


Table A1.14. German $\mathrm{NO}_{\mathrm{x}}$ Standards ( $g / G J$ fuel input)

\begin{tabular}{|c|c|c|}
\hline Source & new & existing \\
\hline \multicolumn{3}{|l|}{ Coal: } \\
\hline $1-2 \mathrm{MW}_{\text {th }}, \mathrm{FBC}^{\mathrm{a} /}$ & 175 & 175 \\
\hline $20.50 \mathrm{MW}_{\mathrm{th}}, \mathrm{FBC}$ & 105 & 105 \\
\hline $1-50 \mathrm{MW}_{\mathrm{th}}$ & 175 & \\
\hline $50-300 \mathrm{MW}$ th & 140 & \\
\hline$>300 \mathrm{MW}_{\text {th }}$ & 70 & \\
\hline PF - dry bottomb/ & & 228 \\
\hline PF - wet bottom & & 455 \\
\hline \multicolumn{3}{|l|}{ Other Solids: } \\
\hline grate firing & & 350 \\
\hline \multicolumn{3}{|l|}{ Fuel Oil: } \\
\hline $\begin{array}{l}\text { 1- } 50 \mathrm{MW}_{\text {th }} \text { (light oil) } \\
1-50 \mathrm{MW} \text { (incl.primary }\end{array}$ & 75 & \\
\hline measures) & 135 & \\
\hline $50-300 \mathrm{MW}_{\text {th }}$ & G0 & 210 \\
\hline$>: 00 \mathrm{MW}_{\text {th }}$ & 45 & 210 \\
\hline \multicolumn{3}{|l|}{ Natural Gas: } \\
\hline$<50 \mathrm{MW}_{\text {th }}$ & 62 & \\
\hline $50-300 \mathrm{MW}_{\text {th }}$ & 62 & 155 \\
\hline$>300 \mathrm{MW}_{\text {th }}$ & 31 & 155 \\
\hline
\end{tabular}

a/FBC -- fluidized bed combustion

b/PF -- pulverized fuel

Table A1.15 German Particulates Standards (g/GJ fuel input)

\begin{tabular}{|c|c|c|}
\hline Source & new & existing \\
\hline \multicolumn{3}{|l|}{ Coal: } \\
\hline$<5 \mathrm{MW}_{\mathrm{th}}$ & 53 & 53 \\
\hline $5-50 \mathrm{MW}_{\text {th }}$ & 18 & \\
\hline$>50 \mathrm{MW}_{\text {th }}$ & 18 & 44 \\
\hline Lignite: & & \\
\hline$>50 \mathrm{MW}_{\mathrm{th}}$ & 18 & 28 \\
\hline Fuel Oil: & & \\
\hline $\begin{array}{l}>5 \mathrm{MW}_{\mathrm{th}} \\
\text { Natural Gas: }\end{array}$ & 15 & 15 \\
\hline$<100 \mathrm{MW}_{\text {th }}$ & 2 & 2 \\
\hline
\end{tabular}


Appendix 2:

Details on the Model Results 
Table A2.1. Energy Demand and Energy Intensities for the BASE Scenario

\begin{tabular}{|l|r|r|r|r|r|}
\hline Parameler & 1988 & 1990 & 1995 & 2000 & 2010 \\
\hline Gross National Product & 100 & 88 & 93 & 117 & 172 \\
(1988=100) & & & & & \\
\hline Final energy demand (PJ)a & 3582 & 2729 & 3165 & 3352 & 3873 \\
\hline Fuel shares (\%): & & & & & \\
\hline - Solid fuels & 37.8 & 26.7 & 30.1 & 27.4 & 20.0 \\
- Liquid fuels & 14.3 & 16.1 & 14.9 & 15.6 & 19.2 \\
- Gas & 13.6 & 15.9 & 15.7 & 16.2 & 18.2 \\
- Electricity & 10.7 & 13.0 & 12.1 & 13.5 & 15.8 \\
- Heat bl & 23.6 & 28.3 & 27.2 & 27.3 & 26.8 \\
\hline Primary energy demand (PJ) & 5387 & 4223 & 4829 & 5071 & 5848 \\
\hline Fuel shares (\%): & & & & & \\
\hline - Hard coal & 65.9 & 61.1 & 61.3 & 58.4 & 55.1 \\
- Lignite & 11.0 & 13.4 & 12.0 & 10.1 & 8.7 \\
- Natural gas & 7.5 & 8.9 & 9.4 & 11.2 & 12.9 \\
- Oil & 13.7 & 15.3 & 15.1 & 17.3 & 18.8 \\
- Other & 1.9 & 1.4 & 2.2 & 3.0 & 4.5 \\
\hline Gross Electricity consumption & 146 & 133 & 149 & 173 & 230 \\
(TWh) & & & & & \\
\hline Energy intensity of GNP & 100 & 89 & 96 & 81 & 63 \\
(1988=100) & & & & & 92 \\
\hline Electricity intensity of GNP & 100 & 102 & 108 & 100 & \\
(1988=100) & & & & & \\
\hline
\end{tabular}

a/Non-energy use of liquid fuels not included

b/Includes district heat and steam and hot water generated in industrial boilers.

Table A2.2. Changes in Sectoral Energy Intensitiesa/ for the BASE Scenario $(1988=100)$

\begin{tabular}{|l|c|r|r|r|r|}
\hline Sector & 1988 & 1990 & 1995 & 2000 & 2010 \\
\hline & & & & & \\
Industrybl & 100 & 109 & 108 & 96 & 79 \\
Construction & 100 & 79 & 70 & 61 & 50 \\
Agriculture & 100 & 75 & 94 & 87 & 84 \\
Transport & 100 & 87 & 88 & 78 & 61 \\
Other sectiors & 100 & 95 & 83 & 69 & 52 \\
Residential & 100 & 70 & 98 & 100 & 107 \\
\hline
\end{tabular}

$\mathbf{a} /$ For residential sector, per capita consumption. For other sectors, consumption per unit of value added, at constant prices b/Excluding energy industries 
Table A23. Emissions of Atmospheric Pollutants by Sectors, BASE Case (thousand tonnes except as noted)

\begin{tabular}{|c|c|c|c|c|}
\hline Pollutant/source & 1988 & 1990 & 2000 & 2010 \\
\hline \multicolumn{5}{|l|}{$\mathrm{SO}_{2}$} \\
\hline Energy conversion & 2848 & 2287 & 2528 & 2967 \\
\hline - PPP and CHPi/ & 2019 & 1584 & 1981 & 2471 \\
\hline - Industrial boilers & 670 & 572 & 414 & 385 \\
\hline - Other & 159 & 131 & 133 & 111 \\
\hline Final users & 979 & 545 & 664 & 608 \\
\hline - Industry & 174 & 133 & 123 & 129 \\
\hline - Transport & 101 & 80 & 104 & 144 \\
\hline - Residential/Commercial & 704 & 332 & 437 & 335 \\
\hline Total & 3827 & 2832 & 3192 & 3575 \\
\hline \multicolumn{5}{|l|}{$\mathrm{NO}_{\mathrm{x}}$} \\
\hline Energy conversion & 627 & 579 & 596 & 630 \\
\hline - PPP and CHP & 421 & 386 & 457 & 498 \\
\hline - Industrial boilers & 150 & 131 & 105 & 100 \\
\hline - Other & 56 & 62 & 34 & 32 \\
\hline Final users & 736 & 608 & 583 & 691 \\
\hline - Industry & 258 & 125 & 134 & 133 \\
\hline - Transport & 520 & 453 & 405 & 515 \\
\hline - Residential/Commercial & 57 & 30 & 44 & 43 \\
\hline Total & 1363 & 1187 & 1179 & 1321 \\
\hline \multicolumn{5}{|l|}{$\mathbf{P M}$} \\
\hline Energy conversion & 1353 & 1013 & 991 & 834 \\
\hline - PPP and CHPa/ & 780 & 574 & 742 & 652 \\
\hline - Industrial boilers & 504 & 369 & 203 & 161 \\
\hline - Other & 69 & 70 & 46 & 21 \\
\hline Final users & 792 & 455 & 472 & 377 \\
\hline - Industry & 347 & 230 & 196 & 171 \\
\hline - Transport & 37 & 30 & 4 & 4 \\
\hline - Residential/Commercial & 408 & 195 & 272 & 202 \\
\hline Total & 2145 & 1468 & 1463 & 1211 \\
\hline $\mathrm{CO}_{2}$ (million tonnes) & 454 & 364 & 432 & 490 \\
\hline
\end{tabular}

a/PPP -- public power plants; CHP - combined heat and power plants 
Table A2.4. Comparison of Scenario Results - Alternative Levels of Controls

BASE

CAC

\begin{tabular}{|l|r|r|r|r|r|r|}
\hline & 1988 & 1990 & 2000 & 2010 & 2000 & 2010 \\
\hline Primary energy demand (PJ) & & & & & & \\
\hline - Hard coal ${ }^{\mathrm{a}}$ - Lignite & 3549 & 2594 & 2966 & 3223 & 2834 & 3095 \\
- Natural gas & 592 & 567 & 511 & 511 & 510 & 513 \\
- Oil & 406 & 374 & 568 & 755 & 635 & 814 \\
- Nuclear & 743 & 643 & 876 & 1100 & 865 & 1091 \\
- Other & - & - & - & - & - & - \\
Total & 97 & 44 & 150 & 259 & 155 & 265 \\
\hline Gross electricity & 5387 & 4223 & 5071 & 5848 & 4999 & 5778 \\
consumption (TWh) & & & & & & \\
\hline
\end{tabular}

Table A2.4., continued

FRRED

\begin{tabular}{|l|r|r|r|r|r|r|}
\hline & 2000 & 2010 & 2000 & 2010 & 2000 & 2010 \\
\hline Primary energy demand (PJ) & & & & & & \\
\hline - Hard coalbI & 2769 & 2910 & 2809 & 3100 & 2860 & 3071 \\
- Lignite & 504 & 440 & 512 & 510 & 513 & 454 \\
- Natural gas & 659 & 847 & 632 & 810 & 642 & 820 \\
- Oil & 870 & 1113 & 865 & 1094 & 870 & 1105 \\
- Nuclear & - & 144 & - & - & - & 82 \\
- Other & 155 & 264 & 154 & 267 & 155 & 264 \\
Total & 4957 & 5718 & 4972 & 5781 & 5040 & 5810 \\
\hline Gross electricity & & & & & & \\
consumption (TWh) & 170 & 226 & 172 & 230 & 177 & 231 \\
\hline
\end{tabular}

a/non-energy use not included

blcoke exports are included in hard coal balance 
Table A25. Emissions of Pollutants - Alternative Levels of Controls (thousand tonnes except as noted)

\begin{tabular}{|c|c|c|c|c|c|c|}
\hline & & & BASE & & CAC & \\
\hline Pollutant/source & $1988 \mathrm{~d}$ & 19900 & 2000 & 2010 & 2000 & 2010 \\
\hline \multicolumn{7}{|l|}{$\mathrm{SO}_{2}$} \\
\hline - new PPPa/ & - & - & 206 & 677 & 30 & 99 \\
\hline - existing PPP & 2019 & 1584 & 1448 & 1329 & 1043 & 882 \\
\hline - new CHP b/ & - & - & 112 & 310 & 11 & 32 \\
\hline - existing CHP & - & - & 215 & 155 & 222 & 155 \\
\hline - industrial boilers & 670 & 572 & 414 & 385 & 349 & 286 \\
\hline - other energy conversion & 159 & 131 & 133 & 111 & 116 & 98 \\
\hline - final users & 979 & 545 & 664 & 608 & 546 & 465 \\
\hline Total & 3827 & 2832 & 3192 & 3575 & 2317 & 2017 \\
\hline \multicolumn{7}{|l|}{$\mathrm{NO}_{x}$} \\
\hline - new PPP & - & - & 42 & 132 & 40 & 130 \\
\hline - existing PPP & 421 & 386 & 308 & 234 & 193 & 151 \\
\hline - new CHP & - & - & 22 & 64 & 18 & 61 \\
\hline - existing CHP & - & - & 84 & 62 & 51 & 37 \\
\hline - industrial boilers & 150 & 131 & 105 & 100 & 62 & 67 \\
\hline - other energy conversion & 56 & 62 & 34 & 38 & 31 & 32 \\
\hline - final users & 736 & 608 & 583 & 691 & 516 & 428 \\
\hline Total & 1363 & 1187 & 1178 & 1321 & 911 & 906 \\
\hline \multicolumn{7}{|l|}{$\mathbf{P M}$} \\
\hline - new PPP & - & - & 7 & 48 & 3 & 36 \\
\hline - existing PPP & 780 & 574 & 498 & 410 & 101 & 103 \\
\hline - new CHP & - & - & 2 & 6 & 1 & 3 \\
\hline - existing CHP & - & - & 235 & 188 & 26 & 18 \\
\hline - industrial boilers & 504 & 369 & 203 & 161 & 100 & 85 \\
\hline - other energy conversion & 69 & 70 & 46 & 21 & 49 & 29 \\
\hline - final users & 792 & 455 & 472 & 377 & 440 & 353 \\
\hline Total & 2145 & 1468 & 1463 & 1211 & 720 & 629 \\
\hline $\mathrm{CO}_{2}$ (million tonnes) & 454 & 364 & 432 & 490 & 423 & 482 \\
\hline
\end{tabular}


Table A2.5, continued

\begin{tabular}{|l|r|r|r|r|r|r||}
\hline \multicolumn{2}{c}{ FRRED } & \multicolumn{3}{c|}{ EEC } & \multicolumn{3}{c|}{ GER } \\
\hline Pollutant/source & 2000 & 2010 & 2000 & 2010 & 2000 & 2010 \\
\hline SO & & & & & & \\
\hline - new PPP & 133 & 332 & 24 & 95 & 21 & 41 \\
- existing PPP & 1001 & 698 & 973 & 530 & 149 & 110 \\
- new CHP & 85 & 170 & 15 & 45 & 8 & 33 \\
- existing CHP & 152 & 83 & 190 & 148 & 41 & 31 \\
- industrial boilers & 301 & 197 & 403 & 386 & 273 & 262 \\
- other energy conversion & 100 & 72 & 133 & 109 & 155 & 224 \\
- final users & 546 & 465 & 546 & 465 & 546 & 465 \\
Total & 2318 & 2017 & 2284 & 1778 & 1193 & 1166 \\
\hline $\mathrm{CO}_{2}$ (million tonnes) & 417 & 461 & 421 & 482 & 427 & 474 \\
\hline
\end{tabular}

a/PPP -- public power plant

b/CHP - combined heat and power plant

c/Data on PPP for 1988 and 1990 include CHP Plants

Table A2.6. Comparison of Scenario Results - Instruments for Large Stationary Sources

\begin{tabular}{|l|r|r|r|r|r|r|}
\multicolumn{1}{c}{} & \multicolumn{3}{c}{ CAC } & \multicolumn{3}{c|}{ ETAX1 } \\
\hline Primary energy demand (PJ) & 2000 & 2010 & 2000 & 2010 & 2000 & 2010 \\
\hline - Hard coal & & & & & & \\
- Lignite & 2834 & 3095 & 2798 & 3071 & 2816 & 3018 \\
- Natural gas & 510 & 513 & 513 & 513 & 513 & 513 \\
- Oil & 635 & 814 & 642 & 779 & 642 & 812 \\
- Nuclear & 865 & 1091 & 832 & 1102 & 850 & 1113 \\
- Other & - & - & - & - & - & - \\
Total & 155 & 265 & 155 & 264 & 155 & 264 \\
\hline Gross electricity & 4999 & 5778 & 4940 & 5729 & 4976 & 5720 \\
consumption (TWh) & & & & & & \\
\hline
\end{tabular}

See notes to Table A2.4 
Table A2.7. Emissions of Pollutants - Instruments for Large Stationary Sources

(thousand tonnes except as noted)

CAC

ETAX1

SO2TR

\begin{tabular}{|l|r|r|r|r|r|r|}
\hline Pollutant/source & 2000 & 2010 & 2000 & 2010 & 2000 & 2010 \\
\hline SO & & & & & & \\
\hline - new PPP & 30 & 99 & 118 & 420 & 112 & 387 \\
- existing PPP & 1043 & 882 & 937 & 386 & 885 & 405 \\
- new CHP & 11 & 32 & 77 & 199 & 64 & 186 \\
- existing CHP & 222 & 155 & 180 & 119 & 194 & 134 \\
- industrial boilers & 349 & 286 & 361 & 332 & 389 & 328 \\
- other energy conversion & 116 & 98 & 94 & 110 & 128 & 112 \\
- final users & 546 & 465 & 546 & 465 & 546 & 465 \\
Total & 2317 & 2017 & 2313 & 2031 & 2318 & 2017 \\
\hline NO & & & & & & \\
\hline - new PPP & 40 & 130 & 37 & 123 & 34 & 121 \\
- existing PPP & 193 & 151 & 187 & 146 & 191 & 147 \\
- new CHP & 18 & 61 & 22 & 64 & 22 & 64 \\
- existing CHP & 51 & 37 & 49 & 36 & 49 & 36 \\
- industrial boilers & 62 & 67 & 68 & 70 & 65 & 69 \\
- other energy conversion & 31 & 32 & 30 & 37 & 27 & 32 \\
- final users & 516 & 428 & 516 & 428 & 516 & 428 \\
Total & 911 & 906 & 909 & 904 & 904 & 897 \\
\hline PM & & & & & & \\
\hline new PPP & 3 & 36 & 3 & 26 & 2 & 27 \\
- existing PPP & 101 & 103 & 84 & 77 & 81 & 78 \\
- new CHP & 1 & 5 & 2 & 6 & 2 & 6 \\
- existing CHP & 26 & 18 & 15 & 11 & 18 & 13 \\
- industrial boilers & 100 & 85 & 196 & 143 & 97 & 69 \\
- other energy conversion & 49 & 29 & 26 & 22 & 54 & 55 \\
- final users & 440 & 353 & 440 & 353 & 440 & 353 \\
Total & 720 & 629 & 766 & 638 & 694 & 601 \\
\hline CO 2 (million tonnes) & 423 & 482 & 418 & 478 & 420 & 476 \\
\hline
\end{tabular}

See notes to Table A2.5 
Table A2.8. Comparison of Scenario Results - Tax on All Fuel Users

\begin{tabular}{|c|c|c|c|c|}
\hline \multicolumn{5}{|c|}{ CAC } \\
Primary energy demand (PJ) & 2000 & 2010 & 2000 & 2010 \\
- Hard coal & & & & \\
- Lignite & 2834 & 3095 & 2625 & 2769 \\
- Natural gas & 510 & 513 & 513 & 513 \\
- Oil & 635 & 814 & 642 & 768 \\
- Nuclear & 865 & 1091 & 894 & 1116 \\
- Other & - & - & - & 152 \\
Total & 155 & 265 & 155 & 264 \\
Gross electricity & 4999 & 5778 & 4829 & 5582 \\
consumption (TWh) & 172 & 229 & 167 & 225 \\
\hline
\end{tabular}

See notes to Table A2.4 
Table A2.9. Emission of Pollutants - Tax on All Fuel Users (thousaind tonnes except as noted)

CAC

ETAX2

\begin{tabular}{|l|r|r|r|r|}
\hline Pollutant/source & 2000 & 2010 & 2000 & 2010 \\
\hline SO, & & & & \\
\hline - new PPP & 30 & 99 & 122 & 321 \\
- existing PPP & 1043 & 882 & 873 & 406 \\
- new CHP & 11 & 32 & 118 & 173 \\
- existing CHP & 222 & 155 & 165 & 106 \\
- industrial boilers & 349 & 286 & 347 & 335 \\
- other energy conversion & 116 & 98 & 79 & 111 \\
- final users & 546 & 465 & 609 & 543 \\
Total & 2317 & 2017 & 2313 & 1995 \\
\hline NOx & & & & \\
\hline - new PPP & 40 & 130 & 28 & 17 \\
- existing PPP & 193 & 151 & 188 & 146 \\
- new CHP & 18 & 61 & 16 & 16 \\
- existing CHP & 51 & 37 & 49 & 36 \\
- industrial boilers & 62 & 67 & 64 & 64 \\
- other energy conversion & 31 & 32 & 28 & 31 \\
- final useis & 516 & 428 & 544 & 608 \\
Total & 911 & 906 & 917 & 918 \\
\hline PM & & & & \\
\hline - new PPP & 3 & 36 & 3 & 23 \\
- existing PPP & 101 & 103 & 80 & 76 \\
- new CHP & 1 & 5 & 2 & 5 \\
- existing CHP & 26 & 18 & 16 & 11 \\
- industrial boilers & 100 & 85 & 191 & 156 \\
- other energy conversion & 49 & 29 & 18 & 21 \\
- final users & 440 & 353 & 434 & 342 \\
Total & 720 & 629 & 744 & 634 \\
\hline CO (million tonnes) & 423 & 482 & 405 & 449 \\
\hline
\end{tabular}

See notes to Table A2.5 
Table A2.10. Comparison of Scenario Results - Coal Tax

\begin{tabular}{|l|r|r|r|r|r|r|}
\hline & \multicolumn{3}{c}{ BASE } & \multicolumn{1}{c}{ CAC } & \multicolumn{3}{c|}{ COALTX } \\
\hline Final energy demand (PJ) & 2000 & 2010 & 2000 & 2010 & 2000 & 2010 \\
\hline - Solid fuels & & & & & & \\
- Liquid fuels & 920 & 773 & 856 & 727 & 654 & 572 \\
- Gas & 524 & 744 & 517 & 723 & 524 & 743 \\
- Electricity & 543 & 703 & 572 & 724 & 543 & 703 \\
- Heat & 450 & 613 & 441 & 597 & 433 & 590 \\
Total & 915 & 1041 & 905 & 1026 & 874 & 1065 \\
\hline Primary energy demand (PJ) & 3352 & 3874 & 3291 & 3797 & 3029 & 3613 \\
\hline - Hard coal & & & & & & \\
- Lignite & 2966 & 3223 & 2834 & 3095 & 2359 & 2442 \\
- Natural gas & 511 & 511 & 510 & 513 & 519 & 522 \\
- Oil & 568 & 755 & 635 & 814 & 642 & 838 \\
- Nuclear & 876 & 1100 & 865 & 1091 & 1043 & 1193 \\
- Other & - & - & - & - & - & 294 \\
Total & 150 & 259 & 155 & 265 & 156 & 261 \\
\hline Gross electricity & 5071 & 5848 & 4999 & 5778 & 4717 & 5549 \\
consumption (TWh) & & & & & & \\
\hline
\end{tabular}

See notes to Table A2.4 
Table A2.11. Emission of Pollutants - Coal Tax (thousand tonnes except as noted)

BASE

CAC

COALTX

\begin{tabular}{||l|r|r|r|r|r|r||}
\hline Pollutant/source & 2000 & 2010 & 2000 & 2010 & 2000 & 2010 \\
\hline SO & & & & & & \\
\hline - new PPP & 206 & 677 & 30 & 99 & 115 & 281 \\
- existing PPP & 1448 & 1329 & 1043 & 882 & 1444 & 1338 \\
- new CHP & 112 & 310 & 11 & 32 & 115 & 317 \\
- existing CHP & 215 & 155 & 222 & 155 & 231 & 176 \\
- industrial boilers & 414 & 385 & 349 & 286 & 531 & 452 \\
- other energy conversion & 133 & 111 & 116 & 98 & 105 & 113 \\
- final users & 664 & 608 & 546 & 465 & 487 & 477 \\
Total & 3192 & 3575 & 2317 & 2017 & 3028 & 3154 \\
\hline NO & & & & & & \\
\hline - new PPP & 42 & 132 & 40 & 130 & 23 & 54 \\
- existing PPP & 308 & 234 & 193 & 151 & 308 & 235 \\
- new CHP & 22 & 64 & 18 & 61 & 18 & 61 \\
- existing CHP & 84 & 62 & 51 & 37 & 84 & 63 \\
- industrial boilers & 105 & 100 & 62 & 67 & 89 & 91 \\
- other energy conversion & 34 & 38 & 31 & 32 & 39 & 46 \\
- final users & 583 & 691 & 516 & 428 & 556 & 669 \\
Total & 1178 & 1321 & 911 & 906 & 1175 & 1288 \\
\hline PM & & & & & & \\
\hline - new PPP & 7 & 48 & 3 & 36 & 3 & 22 \\
- existing PPP & 498 & 410 & 101 & 103 & 498 & 410 \\
- new CHP & 2 & 6 & 1 & 5 & 2 & 6 \\
- existing CHP & 235 & 188 & 26 & 18 & 270 & 255 \\
- inciustrial boilers & 203 & 161 & 100 & 85 & 151 & 156 \\
- other energy conversion & 46 & 21 & 49 & 29 & 40 & 55 \\
- final users & 472 & 377 & 440 & 353 & 336 & 276 \\
Total & 1463 & 1211 & 720 & 629 & 1300 & 1180 \\
\hline CO2 (million tonnes) & 490 & 423 & 482 & 386 & 427 \\
\hline
\end{tabular}

See notes to Table A2.5 
Table A2.12. Costs of Emission Control Measures for Large Stationary and Transport Sources

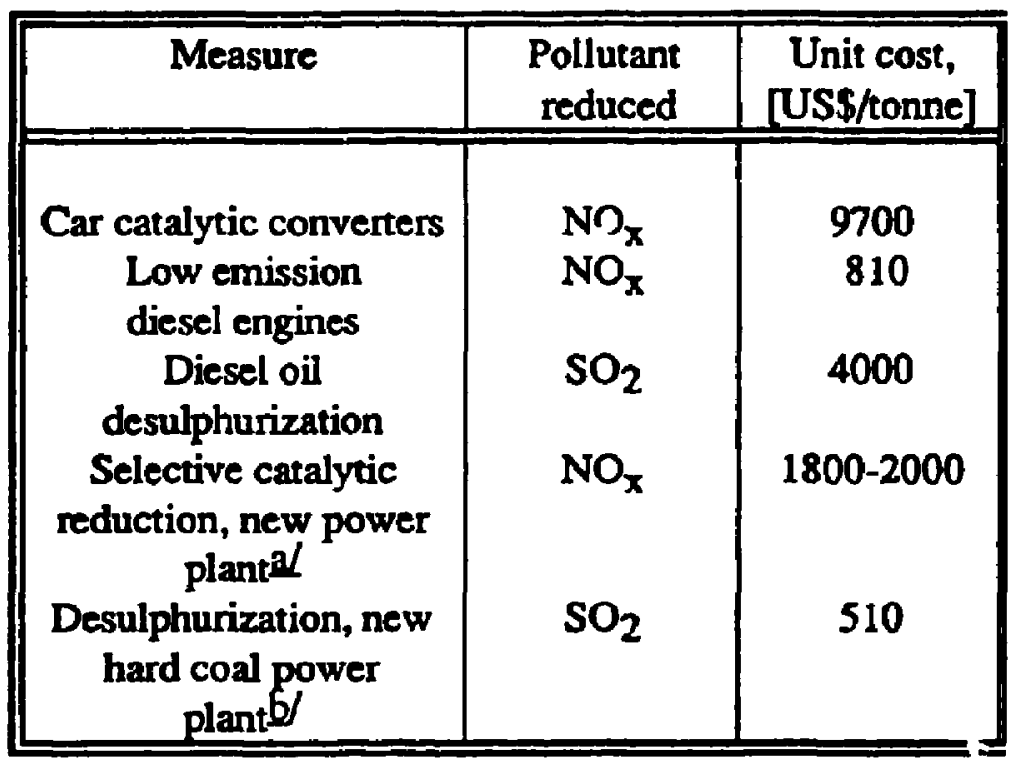

$3 /$ Roughly 35 percent more for combined heat and power plant. b/Assumes $23 \mathrm{GJ} / \mathrm{t}$ calorific value and $1 \%$ sulphur content.

Table A2.13. Total Undiscounted Energy Supply and Conversion Investments

Period

\begin{tabular}{|l|c|c|}
\hline \multicolumn{1}{|c|}{ Scenario } & $199 i-2000$ & $1991-2010$ \\
\hline BASE & 27.1 & 65.7 \\
CAC & 29.2 & 70.2 \\
GER & 38.1 & $i 2.8$ \\
ETAX2 & 27.6 & 71.8 \\
\hline
\end{tabular}


Table A2.14. Production of Hard Coal and Lignite (million tce)

\begin{tabular}{|c|c|c|c|c|c|}
\hline & 1988 & 1990 & 1995 & 2000 & 2010 \\
\hline BASE & $141.2^{\mathrm{a}}$ & $135.2 \mathrm{a}$ & 133.3 & 132.9 & 136.4 \\
\hline $\mathrm{CAC}$ & & & 132.7 & 132.9 & 136.4 \\
\hline FRRED & & & 128.1 & 132.7 & 134.0 \\
\hline EEC & & & 132.7 & 132.9 & 136.4 \\
\hline r.ER & & & 129.9 & 132.9 & 134.5 \\
\hline ETAX1 & & & 129.3 & 132.9 & 136.4 \\
\hline SO2TR & & & 131.6 & 132.9 & 136.4 \\
\hline ETAX2 & & & 130.9 & 132.9 & 134.9 \\
\hline COALTX & & & 133.2 & 129.8 & 133.8 \\
\hline
\end{tabular}

a/Actuals 
The World Bank

Itendejuarters

ISISII Stret. NW

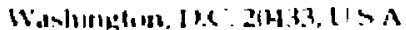

I.

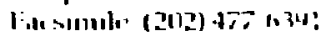

I.

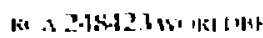

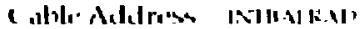

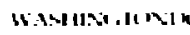

Iiuropedn COffine

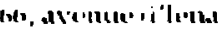

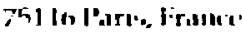

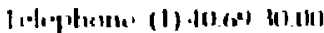

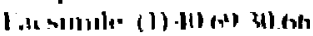

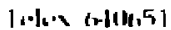

Takyo Office

kiskusas liualeltis:

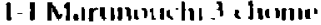

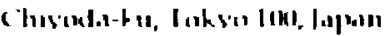

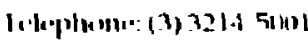

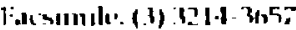

1.1.1. 265 